ARTICLE

Received 18 May 2017 | Accepted 16 Aug 2017 | Published 19 Sep 2017

DOl: $10.1057 /$ palcomms.2017.94

\title{
Metropolitan and city-regional politics in the urban age: why does "(smart) devolution" matter?
}

Igor Calzada ${ }^{1}$

\begin{abstract}
In recent years, two apparently contradictory but, in fact, complementary socio-political phenomena have reinforced each other in the European urban realm: the rescaling of nation-states through "devolution" and the emergence of two opposed versions of "nationalism" (that is, ethnic, non-metropolitanised, state-centric, exclusive, and right-wing populist nationalism and civic, metropolitanized, stateless, inclusive and progressivistemancipatory-social democratic nationalism). In light of these intertwined phenomena, this article shows how an ongoing, pervasive and uneven "metropolitanisation effect" is increasingly shaping city-regional political responses by overlapping metropolitan, cityregional, and national political scales and agendas. This effect is clear in three European cases driven by "civic nationalism" that are altering their referential nation-states' uniformity through "devolution". This article compares three metropolitan (and city-regional) cases in the United Kingdom and in Spain, namely, Glasgow (Scotland), Barcelona (Catalonia) and Bilbao (Basque Country), by benchmarking their policy implementation and the tensions produced in reference to their nation-states. Fieldwork was conducted from January 2015 to June 2017 through in-depth interviews with stakeholders in the three locations. Despite the so-called pluri-national and federal dilemmas, this article contributes to the examination of the side effects of "metropolitanisation" by considering three arguments based on geoeconomics ("prosperous competitiveness"), geo-politics ("smart devolution"), and geodemocratics ("right to decide"). Finally, this article adds to the existing research on metropolitan and city-regional politics by demonstrating why "devolution" matters and why it must be considered seriously. The "metropolitanisation effect" is key to understanding and transforming the current configurations of nation-states, such as the United Kingdom and Spain (as we currently know them), beyond internal discord around pluri-nationality and quasi-federalism. This article concludes by suggesting the term "smart devolution" to promote more imaginative and entrepreneurial approaches to metropolitan and city-regional politics, policies, and experimental democracy within these nation-states. These approaches can identify and pursue "smart" avenues of timely, subtle and innovative political strategies for change in the ongoing re-scaling devolution processes occurring in the United Kingdom and in Spain and in the consequent changes in the prospects for the refoundational momentum in the EU.
\end{abstract}

\footnotetext{
${ }^{1}$ Urban Transformations ESRC and Future of Cities Programme, COMPAS, University of Oxford, Oxford, UK Correspondence: (e-mail: igor.calzada@compas. ox.ac.uk)
} 


\section{Introduction: the metropolitan and city-regional politics that} are re-scaling nation-states

W

hile the world has continuously urbanised, it has also rapidly metropolitanised. This metropolitanisation trend is reinforcing the re-scaling of nation-states through multiple interconnected factors (Brenner, 2009; Gleeson and Spiller, 2012; Fricke and Gualini, 2017; Glaeser and Steinberg, 2017).

In the 1990s, many hyper-globalist scholars forecast the imminent demise of national state power because of the purportedly borderless, politically uncontrollable forces of global economic integration (Ohmae, 1995). However, a growing body of literature on state rescaling has provided a strong counterargument, namely, that nation-states are being qualitatively transformed-not eroded or dismantled-under contemporary capitalist conditions (Brenner, 2004). From a broader historical perspective, Keating (2014b) argues for the re-scaling of nationstates as the politicisation of regional space through claims for devolution from their city-regions (Jonas and Moisio, 2016). In some cases, this phenomenon coincides with strong historical identities, city-regional articulation engines, metropolitan hubs and national diversity, as in the cases this paper will present: Glasgow in Scotland, Barcelona in Catalonia, and Bilbao in the Basque Country. In connection with this concept, Goodwin et al. (2005) examine the devolved structures and strategies for economic development that have been implemented across the United Kingdom in an attempt to increase global economic competitiveness while addressing entrenched social inequalities, recognising cultural and identity politics, and enabling piecemeal democratic rights.

It seems remarkable that the current recentralisation vs. devolution debate (Calzada, 2016a) in the United Kingdom and Spain implies a different starting point from the perspective of political regionalism. However, according to Álvarez Pereira et al. (2017: 1), a common pattern is likely to be followed by devolutionist movements in Western Europe insofar as (city-) "regions being relatively richer than the country to which [they belong] is associated with higher electoral support to regionalist parties only to the extent that the region is culturally differentiated". This understanding is appropriate to the three cases compared in this article, although the context varies with regard to the way the two aforementioned nation-states address devolution (Giordano and Roller, 2003; Burch et al., 2005; Cooke and Clifton, 2005; Conversi, 2007; Allmendinger and Haughton, 2010; Henderson et al., 2013; Convery and Lundberg, 2016; Molina, 2017; Basta, 2017). To some extent, devolution matters insofar as it can be identified as the common driver of "the perpetual fragmentation of territory into ever more (and smaller) units of authority, from empires to nations, nations to provinces, and provinces to cities" (Khanna, 2016b: 63). "Fragmentation" can be seen here as a natural pattern of re-scaling nation-states; in contrast, it can be perceived as a threat to the integrity of the nation-state itself, as is clearly the case for Spain (Colino, 2008; Zabalo et al., 2012; Serrano, 2013; Sanjaume-Calvet and Gagnon, 2014).

Devolution debates were invigorated, albeit in different ways, in 2014 in two pluri-national states, the United Kingdom and Spain (Anderson and Keil, 2017). Whereas the United Kingdom witnessed a Scottish Independence referendum in September 2014 that was agreed upon by the then-Prime Minister of the United Kingdom, David Cameron, and the former Scottish First Minister, Alex Salmond, Spain's central government upheld the territorial unity of the Spanish nation-state and refused any expression of self-determination as demanded by a considerable population in Catalonia (Guibernau et al., 2014; Crameri, 2016). This is once again the case with the announcement made by the
Catalan government of the illegal referendum of 1 October 2017 (Herszenhorn and von Der Burchard, 2017). Another important difference is that the political landscape in the Basque Country over the past 40 years has been dominated by attempts to overcome political violence (Zabalo and Saratxo, 2015; Alvarez Berastegi, 2017). At present, an optimistic peace process is being fuelled by civic society, and there is an attempt to avoid confrontational inertia between the ETA (Euskadi Ta Askatasuna, or Basque Country and Freedom, the armed Basque nationalist and separatist organisation) and the Spanish state (Mediapro, 2017). To this end, there is some progress or, at least, an interest in leveraging self-government and implementing the "right to decide" in the Basque Country (Barceló et al., 2015; Calzada and Bildarratz, 2015; Geller et al., 2015).

The plebiscite on Scottish independence in 2014 (and a potentially forthcoming one between autumn 2018 and spring 2019), the Brexit vote in the United Kingdom in 2016 (Los et al., 2017), and the ongoing quest for the "right to decide" on statehood for Catalonia and the Basque Country in Spain are key yet diverse examples of the way metropolitanisation has triggered a wider political debate (Crameri, 2015,2016; Davidson, 2016). Hence, this article argues that within and beyond nation-states, metropolitan politics are shaping the future of city-regions even beyond the loose notion of pluri-nationality and the federalism of nation-states (Madgwick, 1982; Moreno, 2001; Wilkins, 2004; Morgan, 2007; Chouinard, 2014; Romaniello, 2014; Requejo, 2015; Sorens, 2017). Remarkably, the most pervasive aftermath seems to be that these unevenly socio-politically divided societies are shaping a new understanding of the centrality of city-regions beyond nation-states' power, both institutionally and territorially (Calzada, 2015). Metropolitan politics are thus clearly enabling cities and regions to be substantial international actors (Acuto, 2009,2013; Moreno, 2016b; Therborn, 2017), beyond even their nation-states (Herrschel and Newman, 2017), by setting up an urban political international order that supersedes the Westphalian interstate system consisting entirely of sovereign and homogeneous territorial nation-states (Ruacan, 2017). In this city-centric narrative, we should consider that "cities are hugely dependent on and inter-connected with their regional hinterlands, the fuzzy and protean metrolands for which there is no longer an agreed terminology" in the urban age (Morgan, 2014: 297). This understanding suggests another interpretation of the urban politics that increasingly overlap with metropolitan and city-regional politics with reference to their nation-states. This article aims to present this interpretation by discussing three interlinked factors: "prosperous competitiveness" (Sellers and Walks, 2013), "(smart) devolution" (Scott and Copeland, 2016; Calzada, 2017b), and the "right to decide" (Barceló et al., 2015).

As nation-states are no longer able and/or willing to manage the increasing complexity of their cities and regions, cities and regions have sought to develop greater independence and a stronger presence in the global sphere. According to Herrschel (2002), Barber (2013) and Corijn (2009), city-regions (Scott, 2002) have been among the first to recognise the declining ability -or inclination-of nation-states to maintain economic cohesion and comparable conditions of life and opportunities for all citizens in their constitutive metropolitan and regional realms. Thus, their diverse city-regional political responses show the path dependency of their metropolitan political choices (Table 3, Factors 7 and 14) (Calzada, 2017a). The ongoing evolution of stateless nationalist parties' strategies highlights an increasing city-ness and metropolitan approach to their policy, in contrast to populist right-wing protectionist choices (Massetti, 2009; Massetti and Schakel, 2013; Iraola, 2015; McAngus, 2015; Massetti and Schakel, 2016,2017; Mylonas and Shelef, 2017; Winlow et al., 2017; Woertz, 2017). This clearly suggests the co-existence of 
diverse "nationalistic" approaches (Zamorano, 2017). For instance, in the United Kingdom, city-regional political responses under devolution have been researched extensively by Keating (2005: 453), who concludes that "Scotland is more committed than England to the traditional public sector model, emphasizing egalitarianism and cooperation with the public service professionals. This contrasts with the English emphasis on consumer choice and competition". In the following section, this article will shed light on the diverse city-regional political responses (Morgan, 1999; Giordano and Roller, 2003; Agnew, 2016; Flinders et al., 2016; Harris and Moffat, 2016; Scottish Government, 2016; Casebourne, 2017) that have flourished as a consequence of the political re-scaling of the nation-state and the way these responses have been embodied in two opposite versions of "nationalism" (Anderson, 1991; Hutchinson and Smith, 1994): "ethnic" versus "civic".

\section{Distinguishing diverse city-regional political responses: civic vs. ethnic nationalisms?}

Brexit and the imminent end of the UK's continued membership in the EU have triggered a much wider devolution debate. This debate involves not only the organisation and legitimisation of nation-state power, both institutionally and territorially, but also the way in which metropolitanisation has influenced inclusive/ exclusive migratory political positions regarding welfare state provisions by fuelling two types of "nationalistic" responses, which are the causes of a deep re-scaling process regarding the United Kingdom as a nation-state (Burch et al., 2005; Sato, 2014; McGrattan and Williams, 2017). As the Guardian noted, the Brexit vote could have triggered article 50 , but it could also be seen as a vote for "English independence at the price of English dominance" (Moore, 2017; Overman, 2017).

According to the newest Governance Report 2017 (Hertie School of Governance, 2017: 165), current liberal democracies, such as the United Kingdom and Spain, owe much of their resilience to an ongoing balancing of two leading sources of internal opposition: populism (or popular sovereignty) versus radical pluralism (or minority rights). Thus, the notion of an oppositional momentum in the United Kingdom (at least so far) seems to be clear with regard to making political decisions based on the metropolitan circumstances in which one lives. Research findings on the Brexit vote have confirmed that the voting patterns of "Brexiters" have in common "their age and education profiles as well as the historical importance of manufacturing employment, low income and high unemployment" (Becker et al., 2016: 1), which makes clear the non-metropolitan condition of these "left behind" voters. The outcome of this situation has been a growing sense of disempowerment and alienation among those who are not "in the system" (Walker, 2010).

This issue establishes notions of community, place, and state territory by forcing diverse metropolitan political positions and city-regional political responses (Mumford, 1938). Claims such as "I want my country back" (Penny, 2016; Airey and Booth-Smith,
2017) (as voiced during the Brexit debates in the United Kingdom) or, by contrast, the "right to the city for all" (in reference to refugees, newcomers, and immigrants) are expressions of a growing awareness of metropolitan and spatial differentiation between "winners" and "losers", which undermines the notion of the cohesive nation-state (Hirschman, 1970; Calzada, 2015; Ariño and Romero, 2016). Particularly in England, where territorial regionalisation has become politically eschewed, a subdivision between metropolitan areas and the "rest" has become an alternative approach that relies on patterns of economic performance and relevance (Mitchell, 2002; Sandford, 2002; O'Brien et al., 2004; Bentham, 2007; Leyland, 2011; Keating, 2014c; Headlam and Hepburn, 2015; Willett, 2015; Centre for Cities, 2016; Pike et al., 2016). However, as West (2015: 9) notes, "many people who experience the downsides of diversity simply do not understand why they should be forced to live in alien surroundings as part of some grand social experiment in which they had no say".

Thus, a main hypothesis of this article is that diverse cityregional political responses are determined by metropolitan or non-metropolitan modus vivendi and operandi (Etherington and Jones, 2016). The "metropolitanisation effect" stands out as the distinction between a more visible, articulate and dominant "metropolitan class" and those in the more peripheral, less articulated, non-metropolitan areas has developed into a formidable struggle for influence on national politics and policies. Metropolitanisation may thus show that identities and related political agendas are no longer expressed in territorially homogeneous units circumscribed by clearly demarcated boundaries or borders (Brenner, 2003; Sellers and Walks, 2013). The English case is of particular interest here as discussions of "English devolution" and the Northern Powerhouse have moved from conventional, territorially based devolution to discussions focused on stronger voices for metropolitan areas through directly elected mayors (Morgan, 2001, 2002; Pike, 2002; Sandford, 2002; Willett, 2015; House of Lords, 2016; Parr, 2017; Sandford, 2017; Travers, 2017).

Although metropolitanisation depicts rather heterogeneous city-regional responses, it clearly addresses two contrasting political agendas, both based on "nationalism" as a common denominator (Anderson, 1991; Hutchinson and Smith, 1994; Bollens, 2008; Eriksen, 2010; Suszycki et al., 2010; Sutherland, 2012; Zabalo et al., 2013; Conversi, 2014; Keating, 2014a; Economist, 2016; Harari, 2017; Pattie and Johnston, 2017; Winlow et al., 2017). The term "nationalism" is a slippery concept; this is why politicians find it so easy to manipulate. At its best, it unites the country around common values to accomplish things that people could never manage alone. Here, we should distinguish between two "nationalisms" (Table 1): the first is "ethnic", backwards, xenophobic, right-wing and populist (Simonsen, 2004; Gest, 2016; Judis, 2016; Moffitt, 2016; Müller, 2016; Winlow et al., 2017; Woertz, 2017); the second is "civic", conciliatory, inclusive, forward-looking and emancipatory (Sage, 2014; Keating, 2014a; Geoghegan, 2015; Macwhirter, 2015;

Table 1 | Non-metropolitanised (Ethnic) vs metropolitanised (Civic) nationalisms (applying the conceptual framework suggested by Keating, 2017a)

Conceptual frames of (city-)regional politics (adapted from (Keating, 2017a))

Region as a refraction of social and economic interests

Integrative agenda

Identity construction

Welfare provision

Government focus

Competitiveness

Non-metropolitanised/ethnic nationalism Internally focused

Protectionist

Populist

Exclusive/Conservative

Geo-economics

Bounded ("Them" versus "Us")
Metropolitanised/civic nationalism Externally focused Internationalist Collaborative

Inclusive/Progressivist Geo-democratics Entrepreneurial/Experimental 
Gillespie, 2016; Hassan, 2016; Johns and Mitchell, 2016; Jensen et al., 2017; Pattie and Johnston, 2017). "Civic nationalism" appeals to universal values, such as freedom and equality. In contrast, "ethnic nationalism", which is zero-sum, aggressive and nostalgic, draws on race or history to set the nation apart.

Particularly in Europe, this is the case for three small stateless nations, Scotland, Catalonia, and the Basque Country, whose main metropolitan hubs, Glasgow, Barcelona, and Bilbao, are entirely functioning international actors. This article presents and compares these nations, which are advocating a new, socially progressivist political agenda around "civic nationalism" that appeals to "European" values through collaborative, internationalist, and integrative mechanisms by respecting nations and national communities worldwide. In this context, devolution matters insofar as "devolutionary" claims could increasingly "Europeanise" the regional political agenda through multi-level governance mechanisms (Sellers, 2002; Henderson et al., 2013; Alcantara et al., 2016; Boronska-Hryniewiecka, 2016; Klinke, 2016; Panara and Varney, 2017; Wojan, 2017) in an ongoing push and pull of having "more to say" in the EU, fuelled by an increasing metropolitan drive and bottom-up democratic experimentation regarding the "right to decide". Despite historic and path dependency differences between each case (Factor 14 in Table 3), these three nations claim the "right to decide" as the democratic experimental right to choose their own future beyond the fixed Westphalian order of established nation-states (Calzada, 2014).

Table 1 presents two conceptual frames of (city-)regional politics by distinguishing between the non-metropolitanised or "ethnic nationalistic" and the metropolitanised or "civic nationalistic" versions.

In the following section, amidst the metropolitanisation debate, we will discuss why devolution matters in the broad context of nation-states re-scaling themselves. According to Moisio and Paasi (2013a: 258), "the transformation of the state is impregnated with conflicts, negotiations and compromises between cityregions and national governments and is characterised by selfserving actions and trade-offs". A nation-state's transformation, or re-scaling process, is a multi-scalar process that overlaps metropolitan and city-regional politics in the urban age, as shown in Table 3. A "multi-scalar" reading of the changing nature of statehood has become a widely used approach for nation-state spatiality over the past decade. In light of the continuous recomposition of the nation-state, the term "smart devolution" is used in this article to capture this new dynamic, which goes beyond notions of pluri-nationality and quasi-federalism in the nation-states in the United Kingdom and Spain that this article comparatively interprets (Moreno, 1986; Ohmae, 1993; Keating, 2001; Conversi, 2007; Colino, 2008; Stiglitz, 2015; Paun et al., 2016; Randall and Casebourne, 2016; Scott and Copeland, 2016; Strategy, 2017; Park, 2017; Travers, 2017).

\section{Why does "(smart) devolution" matter? from the "right to the city" to the "right to decide"}

This section discusses the need to consider devolution as a constitutive element of the politics of the urban age in Western nation-states. We present the hypothesis that the "right to decide" can be seen as a new version of a metropolitan-based "right to the city" beyond nation-states. Thus, a demos-driven, selfdetermination 2.0 version, empowered by a wide range of political ideologies around a "civic nationalist" movement, activates a bottom-up and progressivist city-regional political response. According to Harvey (2008: 40), "Lefebvre was right to insist that the revolution has to be urban in the broadest sense of that term". However, in the urban age, the economic sphere is not automatically congruent with the political sphere. Therefore, it remains to be seen whether metropolitan standing and capacity will provide extra agency to small, city-regional, stateless nations (Kay, 2009). On this basis, the strategic "civic nationalistic" ambitions of the three cases presented in this article can be considered an updated or expanded version of a metropolitanbased "right to the city", in Lefebvre's phrase (Purcell, 2014; Steele, 2017). Are the two "rights", the "right to the city" and the "right to decide", comparable in both their conventionally projected sub-national state and subordination to the nationstates and their scope to produce new trans-scalar political dynamics and relations (as shown in Table 3 ) that challenge that hierarchical state structure?

As the main argument of this paper, two intertwined explanations are offered for why "(smart) devolution" matters as the ongoing political expression of the urban age in the context of some Western nation-states, such as the United Kingdom and Spain.

First, new metropolitan and diverse city-regional political responses are emerging, fuelled by devolution (Goodwin et al., 2012; Khanna, 2016b) and self-determination claims (Guibernau, 2013). These claims are expressed and embodied unevenly via geo-democratic practices such as the "right to decide" through referenda. In 2014, a referendum was held in Scotland and "bilaterally" agreed upon with the United Kingdom, whereas in Catalonia, the Catalan parliament and government recently "unilaterally" disobeyed Spanish constitutional imperatives (Factor 15 in Table 3) (Qvortrup, 2014; Barceló et al., 2015; Qvortrup, 2015; Cagiao y Conde, 2016; Cagiao y Conde and Ferraiuolo, 2016; Keating, 2017b).

Second, "metropolitanisation" could be driving these changes (OECD, 2012; Katz and Bradley, 2013; Ahrend and Schumann, 2014; Ortiz, 2014; European Metropolitan Authorities, 2015; OECD, 2015; Clark and Moonen, 2016; Fricke, 2016; OECD, 2016) insofar as these small stateless nations are advocating a new, socially progressivist political agenda around "civic nationalism" by appealing to European values in contrast to "ethnic nationalism".

A broad stream of literature about the metropolitan "revolution" and its socio-economic consequences for ordinary citizens has been produced in the last decade. Whereas Cox (2010) emphasises the metropolitan fragmentation and its political consequences in the United States, Bentham (2007) noted in 1983 that urban problems and public dissatisfaction in the metropolitan areas in England were based on objective rather than subjective indicators. However, these indicators did not necessarily align with the general public's view of which areas had the greatest problems. Similarly, Clark and Moonen (2013) observe the remarkable relevance of dealing with metropolitan "fuzzy" devolution. Clark and Moonen argue that "metropolitan politics are complex but not ungovernable entities that should be put at the heart of international and national macroeconomic policy" (2016: 54). Regarding the post-devolution implemented by the UK government in 1997, Allmendinger and Haughton conclude instead that "conflicts remain and the geographical variability [of] this, not least in the context of devolution" (2010: 816). Given the complexity of metropolitan governance, a straightforward means of addressing the devolution issue at the nation-state level cannot be identified. Moreover, as observed in the section that compares the three cases, the overlapping political scales in the urban agenda provoke a net of multi-directional strategies in the three cases by scaling up from the metropolitan level to the cityregional and national levels and, vice versa, uniquely scaling down through devolution. Hence, this article suggests that insofar as the devolution trend accelerates this overlap, another interpretation of urban politics is required. Table 3 presents an 
empirical policy analysis given that smart city policies are invigorating devolution through metropolitanisation processes in Glasgow, Barcelona and Bilbao because of direct socio-economic consequences (for their metropolitan prosperous competitiveness levels; the geo-economic metropolitan argument) as well as the political (for updating their political status; the geo-political metropolitan argument) and democratic (for deciding their future; geo-democratic metropolitan argument) aftermath (Table 2).

The meaning of devolution is the decentralisation of power. Devolution matters because complex processes of city-regional metropolitanisation are altering the nature of the relationship between the centre and the periphery (Khanna, 2014; Gillespie, 2015; Convery and Lundberg, 2016). These city-regions are pursuing greater devolution deals, whereas their respective nation-states are obsessed with maintaining territorial unity (Rodríguez-Pose and Gill, 2005). However, the established and simplistic state-centric vision that focuses on geo-economic processes no longer suffices (Harrison and Hoyler, 2014; Jonas and Moisio, 2016). Instead, geo-political and geo-democratic dynamics must be included to articulate and enrich a systematic analysis of devolution that goes beyond a focus on reterritorialising and existing nation-states to match relationally defined, diversifying (regional) ideas of nationality, identity, representation and devolutionary ambitions as new geo-political global "connectographies" (Khanna, 2016b). Maps of sovereign states betray the far fuzzier "metropolitan" reality of hundreds of relatively autonomous nodes. These autonomous nodes, which, in the aftermath of the Spanish dictator Francisco Franco, were forced to be integrated in a single national "personality" through language in an "odious homogenisation" (Khanna, 2016b: 64), inevitably resulted in a backlash from the Catalan and Basque national and linguistic communities. Thus, "smart" devolution requires infrastructure investment and the mutually beneficial exploitation of resources. The more peripheral areas witness-but do not partake in-the success of the centre, the more they will push to seize control of their own affairs or claim their "right to decide" their home rule.

In Europe, this post-Brexit era has reinforced two main drivers. First, metropolitanization stands out as the distinction between a more visible, articulate and dominant "metropolitan class" and those living in the more peripheral, less articulated, nonmetropolitan areas has developed into a formidable struggle for influence on national politics and policies. Second, consequently, devolution has become a healthy form of competitive arbitrage through multi-level governance instrumentarium-a perpetual negotiation to obtain maximum freedom from under-performing national governments so that over-performing city-regions can accomplish their own priorities (Gray, 2015; BoronskaHryniewiecka, 2016; Gray, 2016).

These tensions, driven by metropolitan and diverse cityregional politics within nation-states, have been evident not only since the Scottish Independence referendum in 2014 and, recently, the Brexit plebiscite in the United Kingdom (especially in Scotland and Northern Ireland) but also in Spain, where
Catalonia has already begun the unilateral secession process (Moore, 1998; Rovira and Martínez, 2016). This is also the case in the Basque Country, where a completely disarmed ETA has opened new horizons for devolutionary policy-making beyond the "devo-max" deal the Basques achieved by gaining complete fiscal autonomy, with no taxes paid to the central government (Colino, 2012; Zabalo and Saratxo, 2015). However, the Spanish constitution forbids secession. Theresa May recently announced that it was not "the right time" for a second Scottish Independence referendum despite Nicola Sturgeon seeking a place between the United Kingdom and the EU (Financial Times, 2016).

In the following section, three metropolitan arguments will be presented.

\section{Three metropolitan arguments for "(smart) devolution": geo- economics, geo-politics and geo-democratics}

To establish the context for how "(smart) devolution" is taking place, it is first important to understand how the Westphalian interstate system, which consists of sovereign territorial nationstates, is being re-scaled in the aforementioned cases by a "civic nationalism". This is particularly relevant in a European context that is increasingly characterised by multi-level governance (Benson, 2015; Alcantara et al., 2016; Jones, 2016; Klinke, 2016; Mulholland and Berger, 2017; Panara and Varney, 2017) and a polymorphic political and geographic recognition that cityregions are becoming increasingly important "sub-national", "third" or "meso"-level political actors. Specifically, as we will discuss later, this article reinforces the "Europe of regions" thesis (Keating, 2014c) by adding two new dimensions: first, "metropolitanisation" as the geo-economic (Harrison, 2012) and geopolitical (Moisio and Paasi, 2013b) basis for emergent small, stateless city-regional nations; second, the "right to decide" as the geo-democratic basis to transcend the former ethno-political nationalistic argument towards a more experimental democratic notion of city-ness (Calzada, 2017c). These dimensions demonstrate the connection among the devolution claims, metropolitan inclusiveness as a social value and a politically and socially progressivist agenda, as shown in the political programmes of the main "civic nationalist" parties (Sage, 2014; Gillespie, 2016). A reinforcement of this connection is currently occurring in Barcelona, Glasgow, and Bilbao because of transitions towards further bottom-up, participatory, and experimental smart city discourses (Factor 6 in Table 3). To different degrees, these transitions reflect the connection between the empirical analysis in the following section and the aforementioned theoretical argumentation and demonstrate the central role of devolution on urban political scales. It should be noted that these transitions occur in cities where nationalist parties are not in power, as is the case of "Barcelona in Common" with Ada Colau, which clearly depicts metropolitanisation as a new brand, entitled "municipalism" (Shea Baird, 2017). Moreover, this geo-democratic metropolitan argument is being directly confronted in the national-state political arena with the announced referendum of 1 October 2017 (Rovira and Martínez, 2016).

Table 2 | Three metropolitan arguments for "(smart) devolution": geo-economics, geo-politics and geo-democratics

Arguments

Scales and Drivers

Geo-economics Metropolitan: "Prosperous Competitiveness"

Geo-politics

Geo-democratics Nation-state: from the "Right to the City" to the "Right to Decide"
Main references

(Jones et al., 2005; Goodwin et al., 2012; Katz and Bradley, 2013; Ortiz, 2014;

Centre for Cities, 2016; Clark, 2016; OECD/KIPF, 2016; Khanna, 2016a; Harrison et al., 2017)

(Moreno, 2001, 2002; Keating and McEwen, 2005; Khanna, 2016b)

(Purcell, 2013; Calzada, 2014; Barceló et al., 2015; Crameri, 2016; Cagiao y Conde and Ferraiuolo, 2016) 
Moreno argues that interdependence on the old continent goes beyond internal boundary building and the establishment of selfcentred compartments of governance, as occurred with the old Westphalian nation-states (Moreno, 2015). Catalonians, like Scots and Basques, have reiterated their support for further Europeanisation, a process that many aim to make congruent with territorial subsidiarity and home rule. Three metropolitan-civic nationalistic cases embrace the European social model while representing the opposite of the position of the pro-Brexit and Eurosceptics, who are driven by state-centric "ethnic nationalism". The three cases underpin the debate about multi-level governance, the changing nature of the nation-state in the EU, and the relative power of central state governments. This theme is often presented as a debate about whether the nation-state's political authority and capacity to act are being eroded "from below" by the demands of territorially based city-regions or "from above" by the logic of economic and political integration among European nation-states (Caramani, 2004). However, we can also observe in these three cases how the United Kingdom and Spain, as nation-states, are eroding their "particular" sovereignty by disempowering their endogenous capacity for democracy and implementing multi-level governance in the following ways: a) in post-Brexit Scotland, diminishing the "right to decide" to remain part of the EU or to be present in the negotiations (Financial Times, 2016); b) in Catalonia, prosecuting the president of the Catalan parliament for allowing debate on a potential referendum (Crameri, 2016); and c) in the Basque Country, permanently attacking the agreement in the concierto económico, the economic framework agreement with Spain, which includes the contemporary political and symbolic taxation devolution formulae used as the principal asset for Basque self-government (Bourne, 2008; Uriarte, 2015; İrepoğlu Carreras, 2016).

As shown in Table 2, three metropolitan arguments are presented to link the political scales in the urban age from the metropolitan to the city-region and from the city-region to the nation-state. In fact, politics in the urban age has re-scaled nation-states (Sellers and Walks, 2013) by evolving from the initial metropolitan scale defined by the "prosperous competitiveness" agenda (the geo-economic argument (Harrison, 2007)) towards an articulation of quests for self-determination through "(smart) devolution" mechanisms (the geo-political argument (Regelmann, 2016)) and reaching the "right to decide" on their own futures (the geo-democratic argument (Harvey, 2008; Geoghegan, 2015)).

Consequently, three arguments overlap among the metropolitan, city-region and nation-state scales, driven by devolution.

1. The geo-economic argument refers to new forms of citysuburban cooperation, regional coordination, region-wide spatial planning and metropolitan institutional organisation promoted in Western European city-regions (Brenner, 2003; Harrison, 2017). Growing tensions between nation-states and "their" city-regions have resulted in either political rescaling through pervasive devolution (Khanna, 2016b: 63-78) or resistance to such centrifugal pressures (Kyriacou and MorralPalacín, 2015). The financial crisis of 2008 called into question the suitability of the "one-size-fits-all" orchestration of state territoriality through hierarchical, top-down, asymmetric relationships between the centre and subordinated, peripheral spaces (González-Alegre, 2017). Does this mean the political dissolution of nation-states per se (Stanic, 2016)? The increasing visibility and dominant economic position of the main cities (and regions) vis-à-vis the state (Acuto, 2013; Barber, 2013; Herrschel and Newman, 2017; Therborn, 2017) have yielded headlines about "cities going independent", such as the provocatively titled "Devo Met" (Economist, 2014). In conventional "realist" international relations debates, this is heresy; nation-states are fixed and whole geographic entities. However, the growing focus on the economic dimension of statehood (the geo-economic argument) and its territorial and institutional manifestation questions the validity of such familiar assumptions as overly simplistic.

2. This situation leads to the second argument, the geo-political argument, which seeks to capture the continuing struggle within nation-states around newly emerging centres of political identity and agency, whether they are metropolitan or based on small nations. At this stage, two substantial differences occur in reference to the (pluri)nation(al)-states' constitutional arrangements and, thus, their democratic interpretations: (i) bilateralism, understood as a rationalised dialectic and agreed-upon democratic mechanism between nation-states and "their" small, stateless, city-regional nations (in Scotland in 2014); and (ii) unilateralism, understood as the right of a "national" or "metropolitan" community to disobey the constitutional settings when they go against their "right to decide/to the city" through consultations or referenda (in Catalonia now). Owing to the Basque Country's "unique" fiscal devolutionary status, which was "legally" agreed upon with the nation-state, now in the new era characterized as post-violence politics (Ruiz-Vieytez, 2016a, b), there are intertwined devolution claims beyond geo-economics and geopolitics rooted in the "right to decide" or, simply, the right to vote for a new political status - an option rejected by the Spanish parliament in 2005 with the Ibarretxe Plan (Calzada, 2014; Geller et al., 2015). This situation has provoked a more explicit and a more conscious sense of belonging for city-regions as well as an update to the propagated "right to the city" as "individual liberty to access urban resources" (Harvey, 2008: 23). Thus, we come to the third argument: geo-democratics.

3. As globalization has intensified questions about the role and purpose of borders and the territorialities of identities and competitiveness, presumed contiguous state territories have become increasingly brittle (Agnew, 1994; Sassen, 2013). State territorial cohesiveness and continuity are no longer a given, which opens the way to new geo-democratics. Democratic innovations and experiments, such as direct and deliberative democracy embodied as plebiscites, referenda, and binding consultations, allow city-regional communities to exercise the "right to decide" (Fishkin, 2009; Filibi et al., 2011). Thus, just as urbanisation played a crucial role in the absorption of capital surpluses (Harvey, 2008), metropolitanisation currently favours further devolution towards governing selfresponsibility at different urban scales and within different boundaries than the established "nation-states", whether for cities themselves or for city-regions or regions with strong notions of identity or "self-ness". New territorialities in democratic representations seem to be a matter of course. This notion can be clearly observed in smart city policies that have evolved from a top-down to a bottom-up perspective in Barcelona, Glasgow, and Bilbao, which represent intertwining metropolitan and city-regional political responses to civic and democratic representational requirements. Further research is required to examine the correlation between political devolution and smart city discourses presented in Table 3.

These three inter-related arguments for "(smart) devolution" affect the construction of the urban sphere in terms of going beyond established notions of the region as a "natural" subdivision of the state. The point to claims by cities for selfrule as they are deemed to no longer require their national 
capitals and states to filter their (mainly macro-economic) relations with the world (Sassen, 2001; Acuto, 2009; Barber, 2013; Khanna, 2014; Herrschel and Newman, 2017). Discussions about the "metropolitanisation" of multi-level governance in Europe during the 1990s (Benson, 2015) should thus extend to cities and city-regions as distinct entities in an "age of devolution" (Calzada, 2016a, 2018). This age establishes a new geopolitical relationship with the respective nation-state that entails new ways to agree with and implement geo-democratic experiments connected to the original meaning of the "right to the city" and smartness. In essence, "smart devolution" is the democratic process and outcome in which the centre and periphery update and agree upon their ongoing political status. As such, in this article, the definition of the term "smart devolution" is threefold.

(i) “(Smart) devolution" should be a required interpretation of devolution as the driving, pervasive, and global metropolitan trend that provokes an increasing overlap among urban political scales from the metropolitan, city-regional, and nation-state as never before. It suggests that cities are actually transforming politics at the regional level-hence the correlation of geo-political power within nation-states. This trend has direct consequences in the political structures of the nation-states analysed in this paper by increasing the claims for democratic representation by any sub-national units within the nation-states.

(ii) The second meaning of "(smart) devolution" involves the capacity for any nation-state to identify and pursue "smart" avenues of timely, subtle, and innovative political strategies for change in the on-going re-scaling devolution processes occurring in the United Kingdom, Spain and the EU. By using "smart" in parenthesis, the article suggests that this capacity may or may not be attributed to nation-states in reference to their "democratic" modus operandi.

(iii) The third meaning of "(smart) devolution" involves connecting the transitional evolutions of ongoing smart city strategies at the urban scale by examining their effects at the upper levels, such as the metropolitan and city-regional levels. In the three analysed cases, these smart city governance transitions depict bottom-up, participatory, and more democratic representation, which relates closely to our previous theoretical argumentation and preliminary hypothesis (Calzada, 2017b). The working hypothesis is that metropolitanisation processes may reinforce bottom-up smart city practices through devolution at the urban and metropolitan scales (Calzada and Cobo, 2015) by provoking city-regional political responses in favour of further geodemocratic claims and "more to say" in political and urban terms. Not surprisingly, cities such as Glasgow (Jamieson, 2016; STV, 2017), Barcelona (Ríos Fernández, 2017), and Bilbao (Iraola, 2015; Redding, 2015) are fuelling a newly "transformative alliance" around "civic nationalism" by gathering a wide range of "progressivist" civic groups in a new communitarian amalgamation. This idea connects with the distinction between stateless "civic nationalism" and state-centric "ethnic nationalism" (Table 1). It is interesting to note this "metropolitanised/civic nationalism" pattern in cases including Glasgow, Barcelona, and Bilbao that generally connect federalists, former Labour voters, nationalists, secessionists, lefties, and progressivists. In the case of Glasgow, Mann and Fenton argue for "the need to acknowledge both the distinct role of interests of the Scottish middle classes in sustaining Scottish nationhood as well as working class whose support for a British Labour Party has changed significantly as a consequence of deindustrialisation". This information is also applicable to Barcelona and Bilbao (2017: 139).

This resulting "fused" "civic nationalism" with the city as its centre may suggest that strategic nationalist ambitions in small, stateless city-regional nations could be considered an updated and expanded version of a metropolitan-based "right to the city", in Lefebvre words (Purcell, 2014). Are the two "rights" comparable? Based on their sub-national scale and from a conventional international relations perspective, are they mutually subordinate to established nation-states? Is the "right to decide" a potential "democratic" extension of the "right to the city"?

\section{Comparative "(Smart) devolution" policy analysis of three metropolitan and city-regional political cases in Europe: Barcelona (Catalonia), Bilbao (Basque country), and Glasgow (Scotland)}

Much of the question about "(smart) devolution" is closely linked to economic opportunity, actual and/or perceived (Guibernau, 2013; Khanna, 2016b: 68). There is an evaluation of "costs" and "benefits" and a desire to self-manage and use such perceived opportunities to one's own advantage (Sage, 2014): “can we afford full independence economically?" and "which way are we better off-independently or as part of the United Kingdom or Spain?" (Rezvani, 2016). In each case, these questions produce very different city-regional political responses at every scale (Moisio and Jonas, 2017). At first glance, the geo-economic argument resonates as the driver (Table 3). However, smart city transitional discourses indicate that, at the metropolitan scale, the claim for more voice for the people ("People Make Glasgow", as the slogan of one city) is clearly an attempt to call for "smart citizens", a notion that could be inevitably scaled up to the city-regional level to request the "right to decide" on self-determination, regardless of the limitations of the constitutional settings (Fig. 3).

To capture the way geo-democratics occurs differently based on the way each city-regional political response sets its "(smart) devolution" agenda, this section compares three cases by conducting a policy analysis that scales up from metropolitan to city-regional and state-national politics to show how the political scales overlap (Cox, 2013; Clark and Clark, 2014).

This trend towards devolution increasingly affects the formulation and implementation of smart city strategies and policies at the city, metropolitan, city-regional, and national scales. These strategies and policies provoke a new understanding of urban politics in which democratic deliberation and experimentation occur (Keating and McEwen, 2005; Economist, 2014; Hazell, 2015; Polverari, 2015; Paun et al., 2016; Randall and Casebourne, 2016; Scott and Copeland, 2016; Shaw and TewdwrJones, 2017).

This analysis was conducted through in-depth interviews from January 2015 to June 2017 in Glasgow, Barcelona, and Bilbao. In each location, the author interviewed 45 people representing politicians, policymakers, academics, activists/entrepreneurs and citizens. The fieldwork was conducted from two diverse but complementary perspectives. First, it focused on the deconstruction of the transitional smart city governance strategic pathway analysis of the three cases funded by the EU Marie Curie "SmartCityRegions" project. Second, given the remarkable sociopolitical transformation that has occurred in Glasgow, Barcelona, and Bilbao, a summer school on "Political Innovation: Constitutional Change, Self-Government, the Right to Decide, and Independence" was organised to benchmark the three stateless city-regional national contexts (Calzada and Bildarratz, 2015). The summer school was crowdfunded by a wide range of Basque regional institutions and with the support of the RSA (Regional 


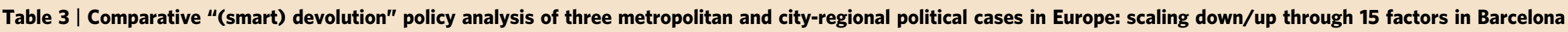
(Catalonia), Bilbao (Basque Country) and Glasgow (Scotland)

\begin{tabular}{|c|c|c|c|}
\hline Comparative "(smart) devolution" policy analysis & $\begin{array}{c}\text { Barcelona (Vallbé et al, 2015; Tomàs, 2016) } \\
\text { Catalonia (Catalonia's Government, 2014) }\end{array}$ & $\begin{array}{c}\text { Bilbao (González, 2004) } \\
\text { Basque Country (Calzada, 2011) }\end{array}$ & $\begin{array}{l}\text { Glasgow (Scottish Cities Alliance, 2017) } \\
\text { Scotland (Scottish Government, 2013) }\end{array}$ \\
\hline \multicolumn{4}{|c|}{ Metropolitan Politics Source: (European Metropolitan Authorities, 2015) } \\
\hline $\begin{array}{l}\text { 1. Municipalities } \\
\text { 2. Surface }\left(\mathrm{km}^{2}\right) \\
\text { 3. Density }\left(\mathrm{Inhabit} / \mathrm{km}^{2}\right) \\
\text { 4. Population } \\
\text { 5. GDP per Capita }(\$)\end{array}$ & $\begin{array}{c}36 \\
636 \\
5,060 \\
3,218,223 \\
36,157\end{array}$ & $\begin{array}{c}35 \\
500 \\
1,820 \\
910,480 \\
38,708\end{array}$ & $\begin{array}{c}5 \\
368 \\
3,171 \\
1,166,928 \\
37,753\end{array}$ \\
\hline
\end{tabular}

6. Smart city governance paradigm and

ongoing transitions (Calzada, 2017b)
- Anti-corporate-uncertain

- From the private-sector-driven smart city "Barcelona" (Adler, 2016) to "Barcelona initiatives in technological sovereignty" (BITS)

- After a large investment in the "smart city strategy" (iBarcelona) (Walt, 2015; Font Monté, and Bria, 2017)
- Corporate-in-transition

- From the corporate/post-Guggenheim effect to Industry 4.0 district in Zorrozaurre.

- After a long time without any comprehensive implementation, "As Fabrik" is presented as the flagship project now.
- Urban-governance-transformative

- From Glasgow smart city to Scottish smart cityregion.

- Two entirely different city-regional political networks has been established: statelessnationalist Scottish cities Alliance and statecentric-unionist core cities.

\section{Scaling from Metropolitan to city-regional politics} 7. "(Smart) devolution" scales' overlaps and contradictions: urban, metropolitan, and cityregional (Fricke and Gualini, 2017: 6)

8. Degrees of devolution, per se

8. Degrees of devolution, per se

\section{Scaling from city-regional to state-national politics}

10. Population in millions (city-regional

contribution to the nation-state \%)

11. GDP (city-regional contribution related to nation-states \%)

12. Paradiplomatic branding

13. City-network composition

14. Strategic drivers of "(smart) devolution" and path-dependency of "metropolitanised/civic nationalisms" (Table 1)
- 1998: Municipal charter. At the municipal level, evolving from top down to bottom up. Still inherent conflict/mismatch between the metropolitan (MAB) (Jones, 2015), the regional (Generalitat) with SmartCat brand (Calzada, 2016b), and the local authority (city council led by Ms. Ada Colau with the new brand, BITS, based on the new "Municipalism") (Shea Baird, 2017).

- 2010: Law of the metropolitan area of Barcelona (MAB).

- In 2010, a Statute aproved by the Catalan parliament was banned by the constitutional court of Spain.

In progress

Very high (After 1 million person demonstration) (Cuadras-Morató, 2016)
- Bottom up by Bilbao metropolitan agency and top down by Biscay province council/Basque region government focuses on Industry 4.0 smart policy and devolution agreement with Madrid. Wider citizenship is required (Holston and Appadura, 2008).

- 1979: Established full fiscal devolution since the 1979: Statute of Autonomy and the concierto 1979: Statute of Autonomy and the concierto state) (Larrea Angulo, 1992: Serrano-Gaztelurrutia, 2012. Uriarte 2015. Spanish Government 2017).

High

Settled down (After post-violence era) (Calzada and Bildarratz, 2015)
- According to Clark et al (2016: 14), fiscal devolution should provide sustained resources for cities to enable them to make major investments in city-regional infrastructure and housing revenues".

- 1998: Scotland Act by New Labour government and first Scottish parliament in 1999 (Cairney, 2014: Clark et al, 2016; Cairney, 2017).

In progress 2014 referendum) (Pike, 2014 Geoghegan, 2015)

\section{$7.5(16 \%)$}

$19 \%$

Olympic games

Football club Barcelona

Barcelona, Tarragona, Girona, Lleida and Països

Catalans*

Driven by civic society:

- November 9, 2014: A non-binding selfdetermination referendum was organised.

- September 27, 2015: A plebiscitary election with unity list in favour of "YES" was announced.

$2.2(5.50 \%)$

$6 \%$

Guggenheim Bilbao Museum Self-government

Bilbao, San Sebastian, Vitoria, Pamplona and BAB

Fixed by institutions:

2017: A new political status update requires the articulation of the "right to decide" beyond constitutional instruments.

- Fiscal autonomy via economic agreement and "right to decide" binding consultation or

\section{$5.3(8 \%)$}

$9 \%$

Commonwealth games

Independence referendum

Glasgow, Aberdeen, Dundee, Edinburgh, Inverness, Perth and Stirling

Facilitated by government:

2016: EU referendum and the potential second independence referendum.

- Devo-max, Brexit and second independence referendum in 2018-2019? 


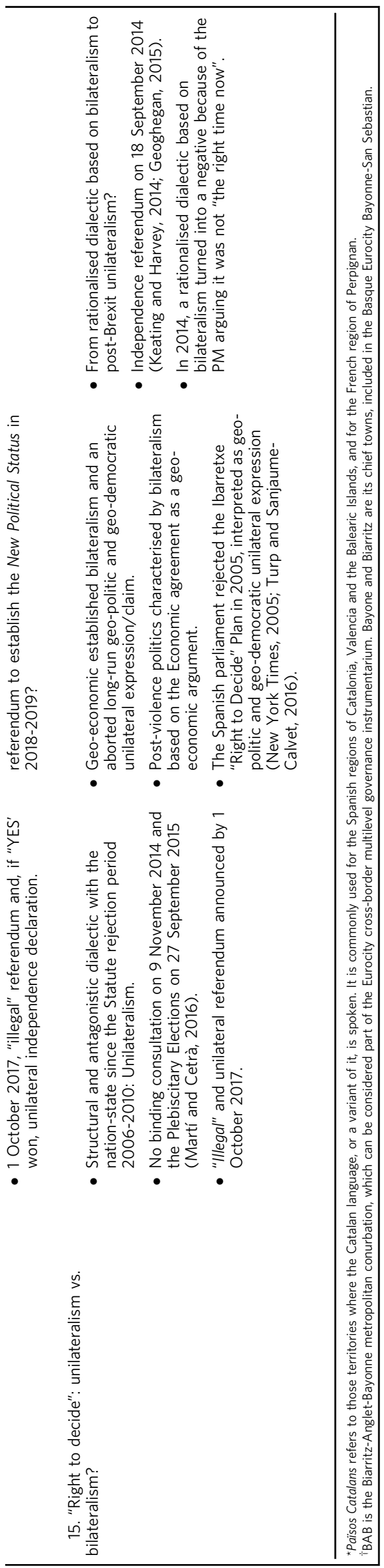

Studies Association) "Smart City-Regional Governance for Sustainability" research network (Dierwechter et al., 2017).

In Catalonia, the 27 September 2015 Catalan regional election was framed as a proxy for an independence referendum by the "devolutionist" parties. These parties were understood to be not only the pro-independence parties but also the federalist statecentric parties that were in favour of the "right to decide", though not necessarily in favour of independence at that stage (Martí and Cetrà, 2016). Since then, the new government has explicitly expressed the goal of holding a referendum in 2017, specifically on 1 October. The controversial turning point occurred in 2006, when a new Statute of Autonomy was approved by the Catalan parliament and was supported by $74 \%$ of votes cast in a referendum. However, it was banned in 2010 by the Spanish Constitutional Court. This event led to massive demonstrations in Catalonia calling for the "right to decide" their own future as a "nation" (Rokkan et al., 2007). This phenomenon has been studied by scholars from diverse ideologies who advocate various solutions to the territorial tension from either the federalist or secessionist side of the debate (Coppieters, 2010; Guibernau, 2013; Barceló et al., 2015; Requejo, 2015; Moreno, 2016a; Cagiao y Conde and Ferraiuolo, 2016). The hegemonic Catalan feeling that was previously driven by pragmatism has turned secessionist because of a lack of faith in a federal agreement given the recentralist, defensive, uncommunicative strategy of the Spanish government (Serrano, 2013). The "right to decide" thus became the motto (Calzada, 2014).

Since then, the goals in Catalonia have been to reinforce the majority of votes in parliament and to design an operative plan to "disconnect" from Spain after the referendum in 2017. This has recently provoked a negative response from the central government, which is prosecuting Catalan MPs. In these tumultuous events, Barcelona plays a unique, pivotal role insofar as the elected activist mayor, Ada Colau, representing the new radical left party "Barcelona In Common", has revitalised her municipal powers by embracing global initiatives of cities in exactly the way Barber (2013), Corijn (2009), Harvey (1997), and Sassen (2002), among many others, suggest. As such, Colau shows an ambivalent "urban/ metropolitan"-based strategy regarding the tension between Catalonia's claim for the "right to decide" and Spain's (re-) centralist approach. Although Colau does not favour secession as influenced by municipally devolution-based federal political principles, she ambivalently supports the referendum and the application of the "right to decide", not only as the representative of the internationalised capital city of the city-region, Barcelona, but also as a relevant part of Catalonia. The Municipal Charter and Metropolitan Area of Barcelona (MAB) provides the framework for the devolution of institutional powers in smart city projects regarding urban planning, infrastructure, education, social services and culture, and it offers greater financial resources to cover those responsibilities. Thus, as Serrano (2013: 541) argues, "Opposition by the Spanish central government to delivering greater fiscal powers to Catalonia as a region has effectively been bypassed". The independence scenario has gained "realness" and more political acceptability, paralleling a bottom-up smart city re-activation founded as "Technological Sovereignty" (Fig. 1).

In the case of Bilbao and the Basque Country, after suffering from the spiral of political violence between the ETA organisation and the Spanish state, the recent official announcement of the full disarmament of the ETA suggests that this era is being left behind (Jeram and Conversi, 2014). After the ceasefire announced by the ETA organisation in 2011, political parties have been pursuing a normalised context in which they can express support for projects (including independence) without the threat of political unrest and violence, which puts further "(smart) devolution" at stake. There has been an intensive and committed effort by 


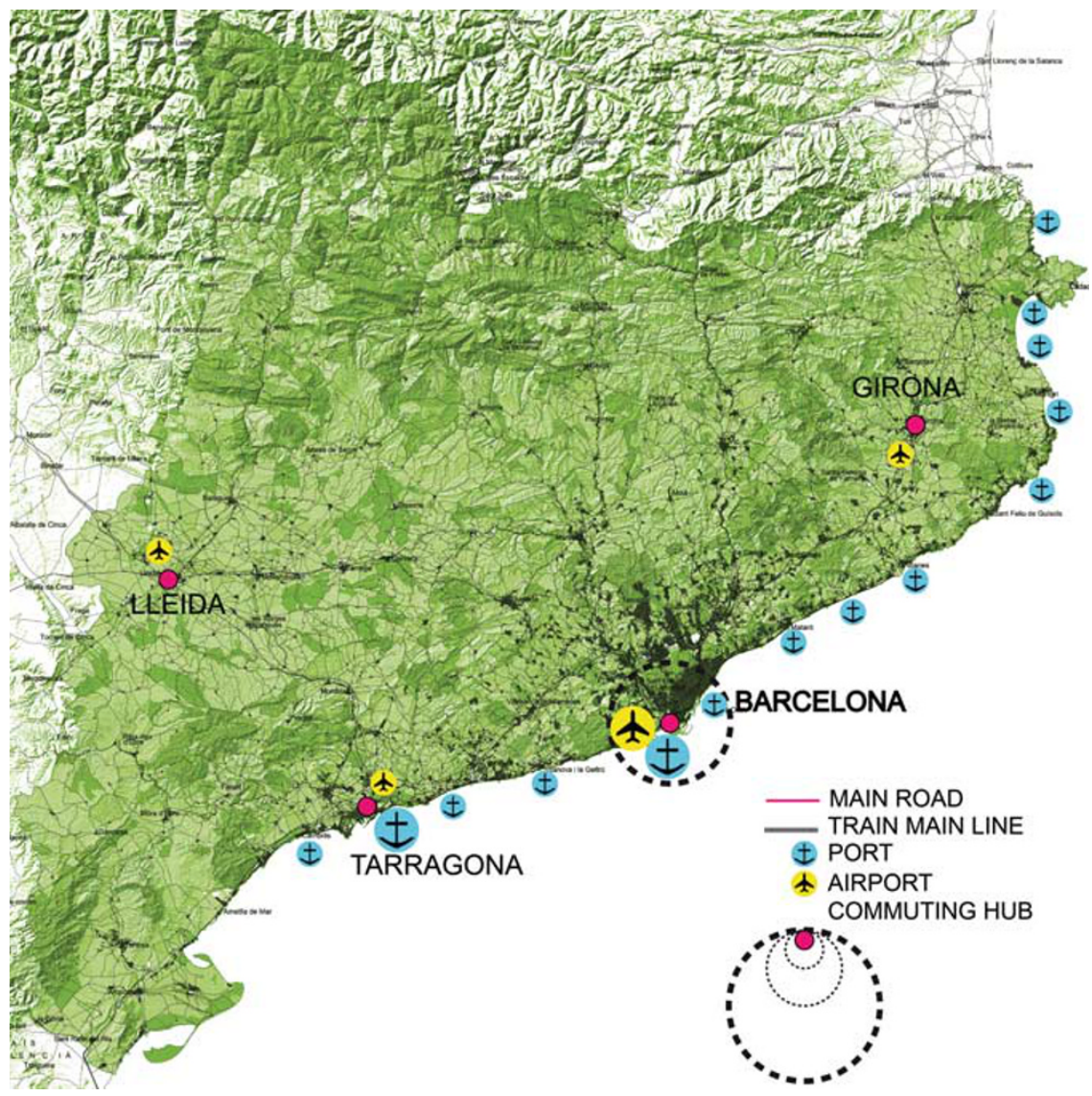

Figure 1 | Barcelona as the metropolitan political hub and Catalonia as the city-regional political response in reference to Spain. [Permission granted to be published under an Open Access license (CC-BY)]. Source: http://cityregions.org/comparative-territorial-connection/empirical-approach/ catalonia. This figure is covered by the Creative Commons Attribution 4.0 International License. Reproduced with permission of Dr Igor Calzada, MBA (www.cityregions.org); copyright (c) Dr lgor Calzada, MBA (www.cityregions.org), all rights reserved.

metropolitan and city-regional institutions and from the broader civic society to cure wounds. In this context, devolution claims may not be radicalised insofar as the self-government policy driven by the Economic Agreement (Gray, 2015; Uriarte, 2015) has wide support from Basque society as a source of social and economic well-being in the last 30 years, which has been actively capitalised on by "civic nationalistic" policymaker advocates (Zabalo et al., 2012). Self-government, which is understood as total tax policy devolution and some capacity to act on policy and political devolution, is legitimised both in the Basque Autonomous Community and in the Statutory Community of Navarra. These are the only two regions in Spain with this unique "historic devolved privilege" (for those Spanish "ethnic nationalists" against it) or "responsibility" (for the entire Basque society, according to surveys) (Ruiz and Fernández, 2003; Joumard and Giorno, 2005; Zabalo et al., 2016). A key role has been played by Bilbao's smart city corporate-intransition transformation in just a few decades (since the late 1980s/early 1990s); it has changed from a city of iron, symbolised by large, polluting steel furnaces, to an international place of culture and urbanity that is characterised by the iconic and world-renowned Guggenheim Museum, which opened in 1997 (González, 2004; Keating and Frantz, 2004; González, 2011). Although the smart city policy has been entirely corporate thus far, a metropolitan push towards a democratic approach is occurring in several niche experiments, such as Zorrozaurre (Calzada, 2017b). (Fig. 2).
Finally, Scotland is recognised as a constituent nation of the United Kingdom, unlike Catalonia and the Basque Country, which are simply called "nationalities" in the Spanish Constitution. This issue of "nation" versus "nationality" reinforces the "indivisib[le] unity of the Spanish nation" and is the principal source of conflict with Spain in the case of Catalonia and the Basque Country (Colino, 2008; Calzada, 2016a). Scottish autonomy was newly conferred in a referendum in 1997. It was established by the Scotland Act and passed by the New Labour government in 1998, which led to the election of the first Scottish parliament in May 1999 and the formation of a new Scottish devolved government in charge of wide-ranging policy fields, including healthcare, education and energy (McLean, 2001; Heald and McLeod, 2005; Jones et al., 2005; Keating, 2005; McGregor and Swales, 2005; Leyland, 2011; Cairney, 2014; Hazell, 2015; Polverari, 2015; ICE, 2016). Thus, Scotland has been gaining political and policy devolution fuelled by the new Scottish Government (Scottish Government, 2013), which has established a smart city-regional strategic vision through the Scottish Cities Alliance (2017) to foster a bottom-up, participatory, and geodemocratic culture within city-regional stakeholders. This is the same government that held the independence referendum in 2014 and obtained votes from 56 of 59 MPs from Scotland in 2015 and lost 21 MPs in the 2017 UK General Elections. The Scottish public has greater levels of trust in Holyrood than in Westminster and, arguably, in the SNP than in the Labour Party (at least in Glasgow), and the SNP's sentiments go beyond the claim for 


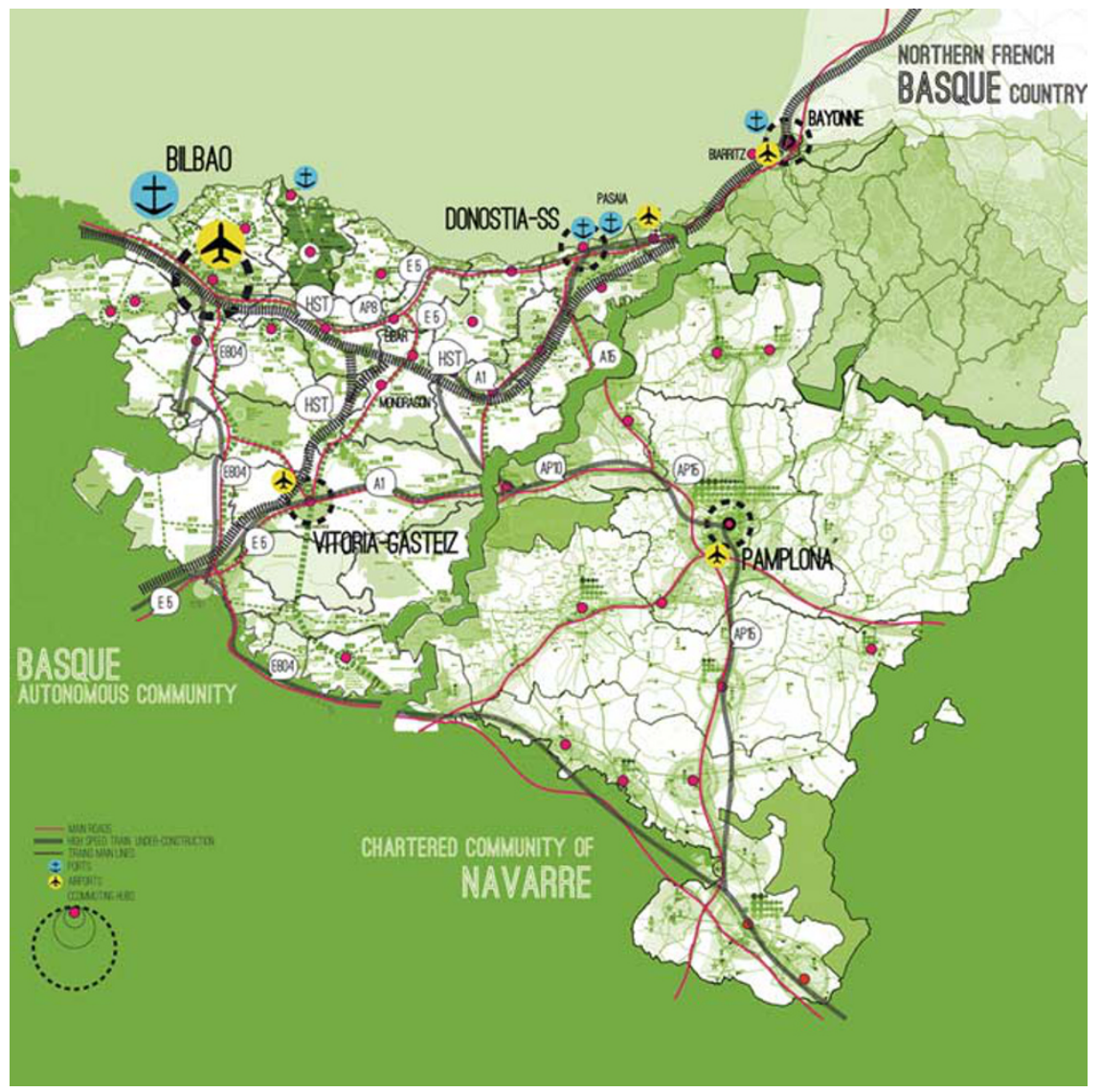

Figure 2 | Bilbao as the metropolitan political hub and the Basque Country as the city-regional political response in reference to Spain. [Permission granted to be published under an Open Access license (CC-BY)]. Source: http://cityregions.org/comparative-territorial-connection/empiricalapproach/basque. This figure is covered by the Creative Commons Attribution 4.0 International License. Reproduced with permission of Dr Igor Calzada, MBA (www.cityregions.org); copyright (c) Dr Igor Calzada, MBA (www.cityregions.org), all rights reserved.

further fiscal devolution (Devine, 2001; Burn-Murdoch, 2017; Scottish Cities Alliance, 2017). Glasgow has gained metropolitan and international visibility that accompanies a sharper political profile and distinct democratic standing (Geoghegan, 2015; Clark et al., 2016). In both referenda for independence and Brexit, Glasgow set the main trend (Macwhirter, 2015; Clark, 2016; Hassan, 2016; Calzada, 2017b). Thus, even though independentists/secessionists were defeated by the small margin of $45 \%$ vs. $55 \%$, the rational way in which the independence debate occurred demonstrated constructive pros and cons that were not seen in Catalonia (BBC News, 2014; Basta, 2015; BBC Radio, 2015). However, after the Brexit vote, in the "age of devolution", there is the question of how to respect the people of Scotland's vote to remain part of the EU.

To conclude the comparative analysis, the empirics articulate the theory by arguing that "(smart) devolution" (i) is presented as a novel and pervasive metropolitan trend as shown in the three cases and (ii) is characterised by high levels of overlapping and scaling down/up among the urban, metropolitan, city-regional, and nation-state levels (iii) by subtly establishing an intertwined reciprocal relationship between political devolution and transitional smart city discourses and practices (iv) to explore another interpretation of the politics in the urban age, (v) even provoking contradictions between political scales (vi) but ultimately fostering more imaginative and entrepreneurial approaches towards devolution between the growing interdependent relationship of cities, small stateless city-regional nations, and nation-states.
Final remark: is the Urban age refounding "devolved" politics in the UK and Spain and, ultimately, in the EU?

This article presented a comparative description of three cases to better understand why "devolution" matters and how "smart devolution" should be implemented between metropolitan and city-regional political responses within two specific nation-states, namely, the United Kingdom (Cooke and Clifton, 2005) and Spain (Costa-Font and Rico, 2006).

In doing so, this article has noted the distinction between "ethnic" and "civic" "nationalisms" in the context of three particular cases in Europe, Scotland, Catalonia, and the Basque Country, which are advocating the "right to decide" as a new version of a metropolitan-based "right to the city" mechanism, led by their metropolitan hubs, Glasgow, Barcelona, and Bilbao, in coherence with inclusive European values.

Considering the eventful years for "devolutionist" movements in both the United Kingdom and Spain since 2014, we can conclude that Glasgow, Barcelona, and Bilbao are strongly fuelling the democratic debate between the community-based city-regions and their respective nation-states (Coppieters, 2010; Turp and Sanjaume-Calvet, 2016; Anderson and Keil, 2017). "Devolution" matters more than ever before because of geo-economic arguments that claim that the devolved powers could be substantial. However, in the event of permission to hold a referendum by nation-states, however likely or unlikely, geo-political and geo-democratic manifestations count even more. 


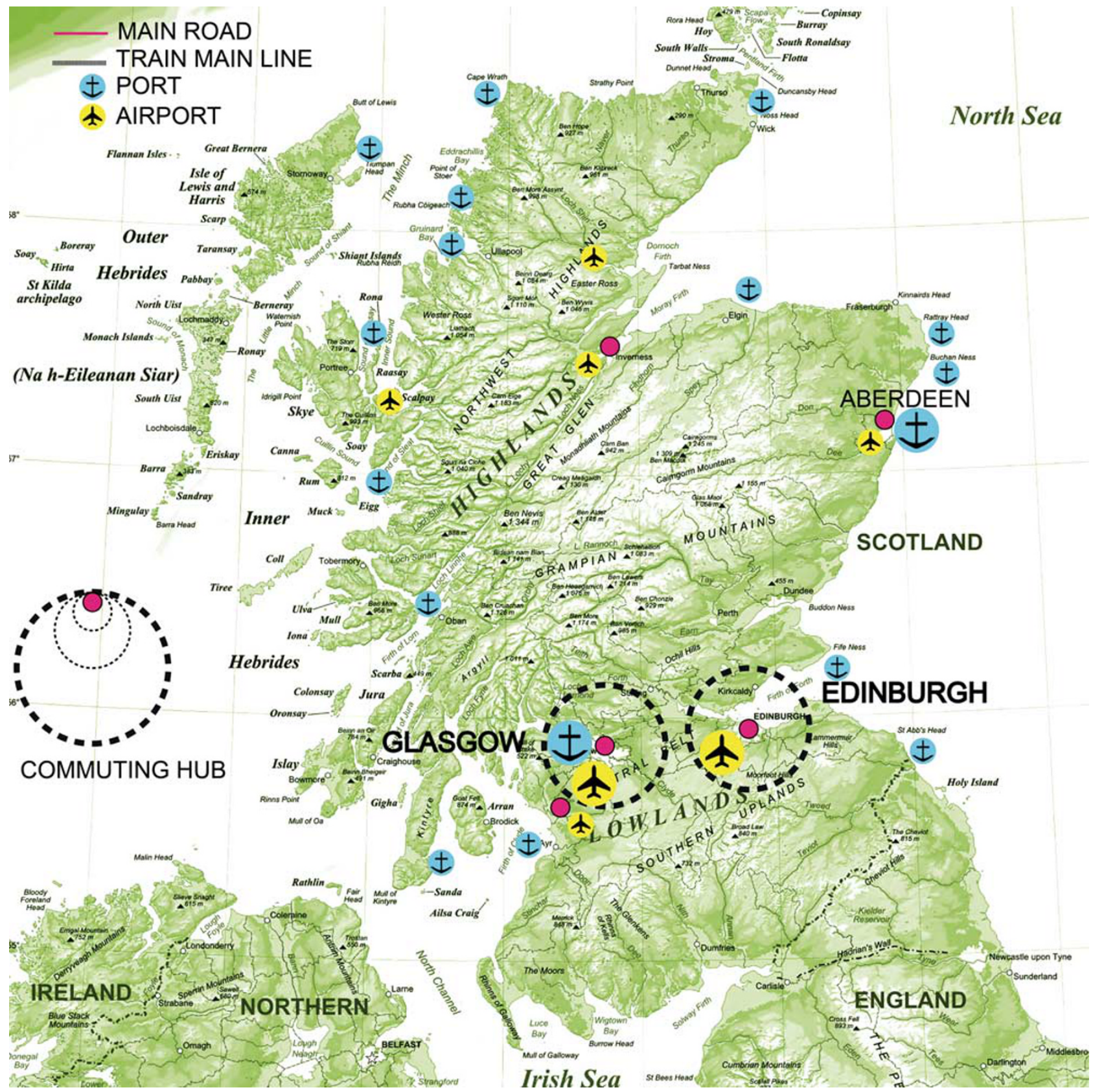

Figure 3 | Glasgow as the metropolitan political hub and Scotland as the city-regional political response in reference to the United Kingdom. [Permission granted to be published under an Open Access license (CC-BY)]. Source: http://cityregions.org/comparative-territorial-connection/ empirical-approach/scotland. This figure is covered by the Creative Commons Attribution 4.0 International License. Reproduced with permission of Dr Igor Calzada, MBA (www.cityregions.org); copyright (c) Dr Igor Calzada, MBA (www.cityregions.org), all rights reserved.

The EU's regional policy and multi-level governance provide an important instrumentarium and a platform for international outreach by sub-national actors in the pursuit of their own increasingly well-articulated interests and priorities (Bourne, 2008, 2014; Eising, 2017; Plangger, 2017; Royles, 2017). This is the case for Scotland, Catalonia and the Basque Country, whose strategic positions within the regional political arena have been empowered by the EU through their active economic sectorial leadership, their influential "lobbying" and networking, and their construction of "metropolitan" spaces with a clear European dimension.

Whereas the domestic argument of legitimacy often works to mobilise the support base, the international dimension seems crucial to those who want to join a "society of states" in the EU. In this respect, the current context requires the adoption of an anticipatory and active role for the EU (Friend, 2012; Augestad Knudsen, 2013; Avery, 2014). In this sense, Connolly argues (2013: 12) that "devolution" and the "right to decide", currently understood as the right to self-determination or secession in international law, "provide little guidance for addressing separatist claims of stateless nations in Europe or other parts of the world".

To conclude, in Europe, "devolution" claims will increasingly be shaped by the institutions of the $\mathrm{EU}$ as part of the ongoing push and pull of having "more say" in the EU. Current interactions between member states and their 
"constitutive" small, stateless city-regional nations are fuelled by an increasing "metropolitan" drive, a bottom-up exercise towards smart and experimental democratic practices for the "right to decide" and, ultimately, an urgency to adopt not only policy and fiscal schemes but also political and democratic "(smart) devolution" schemes.

\section{References}

Acuto M (2009) Global cities as actors: A rejoinder to Calder and de Freytas. SAIS Review of International Affairs; 29 (2): 175-178.

Acuto M (2013) Global Cities, Governance and Diplomacy: The Urban Link. Routledge: London.

Adler L (2016) How Smart City Barcelona Brought the Internet of Things to Life [Online]. Harvard University: Harvard, UK.

Agnew J (1994) The territorial trap: The geographical assumptions of international relations theory. Review of International Political Economy; 1 (1): 53-80.

Agnew J (2016) Spatializing politics. Territory, Politics, Governance; 4 (3): 265-268.

Ahrend RCG and Schumann A (2014) The OECD Metropolitan Governance Survey. OECD Publishing: Paris, France.

Airey J and Booth-Smith L (2017) The Making of An Industrial Strategy: Taking Back Control Locally. Localis: London.

Alcantara C, Broschek J and Nelles J (2016) Rethinking multilevel governance as an instance of multilevel politics: A conceptual strategy. Territory, Politics, Governance; 4 (1): 33-51.

Allmendinger P and Haughton G (2010) Spatial planning, devolution, and new planning spaces. Environment and Planning C: Government and Policy; 28 (5): 803-818

Alvarez Berastegi A (2017) Transitional justice in settled democracies: Northern Ireland and the Basque Country in comparative perspective. Critical Studies on Terrorism; 10 (3): 1-20.

Álvarez Pereira B, Portos M and Vourdas J (2017) Waving goodbye? The determinants of autonomism and secessionism in Western Europe. Regional Studies; 52 (1): 1-15.

Anderson B R O G (1991) Imagined Communities: Reflections on the Origin and Spread of Nationalism. Verso: London.

Anderson P and Keil S (2017) States falling apart? Secessionist and autonomy movements in Europe. Regional \& Federal Studies; 27 (1): 99-101.

Ariño A and Romero J (2016) La secesión de los ricos. Galaxia Gutenberg: Barcelona.

Augestad Knudsen R (2013) Moments of Self-determination: The concept of 'selfdetermination' and the idea of freedom in 20th and 21st century international discourse. London School of Economics and Political Science: London.

Avery G (2014) Independentism and the European Union. European Policy Centre: Brussels, Belgium.

Barber BR (2013) If Mayors Ruled the World: Dysfunctional Nations, Rising Cities. Yale University Press: New Haven, CT.

Barceló M, Corretja M, González A, López J and Vilajosana JM (2015) El derecho a decidir: Teoría y práctica de un nuevo derecho. Atelier: Barcelona, Spain.

Basta K (2015) Whatever the result of the Catalan elections, both Catalonia and Spain are now entering uncharted territory, http://blogs.lse.ac.uk/europpblog/ 2015/09/22/whatever-the-result-of-the-catalan-elections-both-catalonia-andspain-are-now-entering-uncharted-territory, accessed 1 April 2017.

Basta K (2017) The state between minority and majority nationalism: Decentralization, symbolic recognition, and secessionist crises in Spain and Canada. Forthcoming in Publius: The Journal of Federalism; pjx048, 1-25.

BBC News. (2014) Scotland Decides - Scotland Votes No [Online]. BBC: London. BBC Radio. (2015) The Invention of Spain. BBC Radio: London.

Becker SO, Fetzer T and Novy D (2016) Who Voted for Brexit? A Comprehensive District-Level Analysis. University of Warwick - Centre for Competitive Advantage in the Global Economy - Department of Economics: Warwick, UK.

Benson D (2015) Policies within the EU multi-level system. Regional \& Federal Studies; 25 (3): 323-325.

Bentham CG (2007) Urban problems and public dissatisfaction in the metropolitan areas of England. Regional Studies; 17 (5): 339-346.

Bollens SA (2008) The city, substate nationalism, and European governance. Nationalism and Ethnic Politics; 14 (2): 189-222.

Boronska-Hryniewiecka K (2016) Multilevel Governance and Regional Empowerment: The Basque Country in the European Union. Center for Basque Studies, University of Nevada, Reno: Reno, NV.

Bourne AK (2008) The European Union and the Accommodation of Basque Difference in Spain. Manchester University Press: Manchester, UK.

Bourne AK (2014) Europeanization and secession: The cases of Catalonia and Scotland. Journal on Ethnopolitics and Minority Issues in Europe; 13 (3): 94-120.

Brenner N (2003) Metropolitan institutional reform and the rescaling of state space in contemporary Western Europe. European Urban and Regional Studies; 10 (4): $297-324$
Brenner N (2004) New State Spaces - Urban Governance and the Rescaling of Statehood. Oxford University Press: Oxford.

Brenner N (2009) Open questions on state rescaling. Cambridge Journal of Regions, Economy and Society; 2 (1): 123-139.

Burch M, Gomez R, Hogwood P and Scott A (2005) Devolution, change and European union policy-making in the UK. Regional Studies; 39 (4): 465-475.

Burn-Murdoch A (2017) Financial Scrutiny Unit Briefing: City Region Deals. Scottish Parliament: Edinburgh, UK.

Cagiao y Conde J (2016) El pluralismo nacional en serio. Público, https://ctxt.es/es/ 20161228/Firmas/10235/Nacionalismos-pluralismo-Pais-Vasco-CatalunyaJorge-Cagiao-y-Conde.htm, accessed 26 July 2017.

Cagiao y Conde J and Ferraiuolo G (2016) El encaje constitucional del derecho a decidir: un enfoque polémico. Catarata: Madrid, Spain.

Cairney P (2014) The territorialisation of interest representation in Scotland: Did devolution produce a new form of group-government relations? Territory, Politics, Governance; 2 (3): 303-321.

Cairney P (2017) Westminster and the devolved institutions [Online]. Edinburgh, UK, https://paulcairney.wordpress.com/2017/05/19/westminster-and-thedevolved-institutions/, accessed 19 May 2017.

Calzada I (2011) ¿Hacia una Ciudad Vasca? Aproximación desde la Innovación Social. Servicio de Publicaciones del Gobierno Vasco: Vitoria-Gasteiz, Spain.

Calzada I (2014) The right to decide in democracy between recentralisation and independence: Scotland, Catalonia and the Basque country. Regions Magazine; 296 (1): 7-8.

Calzada I (2015) Benchmarking future city-regions beyond nation-states. Regional Studies, Regional Science; 2 (1): 351-362.

Calzada I (2016a) Between Independence \& Re-Centralisation: Political Innovation in an Age of Devolution. [Online]. Oxford: Politics in Spires, http://blog.politics. ox.ac.uk/between-independence-and-re-centralisation, accessed 1 April 2017.

Calzada I (2016b) (Un)Plugging smart cities transformations and strategies in Europe. In: Whitepaper Harvard University (ed). 2016 Strategic Innovation Summit: Smart Cities Europe. Dublin City Council, Maynooth University and the Technology and Entrepreneurship Center at Harvard University in Dublin: Dublin, Ireland.

Calzada I (2017a) Metropolitan and post-national urbanity beyond (Pluri)Nation (al)-States in the EU: Benchmarking Scotland, Catalonia and the Basque Country. JEMIE Journal on Ethnopolitics and Minority Issues in Europe; 16 (1): 51-78.

Calzada I (2017b) The techno-politics of data and smart devolution in city-regions: Comparing Glasgow, Bristol, Barcelona, and Bilbao. Systems; 5 (1): 18.

Calzada I (2017c) Urbanitat postnacional més enllà de l'estat (pluri)nacio(nal) en la UE: comparant Escòcia, Catalunya i el País Basc. Debats. Revista de cultura, poder i societat. Institució Alfons el Magnanim; 131 (1): 51-63.

Calzada I (2018) Political regionalism in the age of devolution in Europe Metropolitanitasation and the right to decide. In: Paasi A, Harrison J and Jones M (eds). Handbook on the Geographies of Regions and Territories. Edward Elgar: Cheltenham, UK and Northampton, MA.

Calzada I and Bildarratz J (2015) Political Innovation: Constitutional Change, SelfGovernment, The Right to Decide \& Independence. Translokal Publishing Academic Entrepreneurship for Policy Making: Donostia, Spain.

Calzada I and Cobo C (2015) Unplugging: Deconstructing the smart city. Journal of Urban Technology; 22 (1): 23-43.

Caramani D (2004) The Nationalization of Politics: The Formation of National Electorates and Party Systems in Western Europe. Cambridge University Press: Cambridge.

Casebourne J (2017) What's next for devolution in England? [Online], http://www. csap.cam.ac.uk/news/article-devolution-england, accessed 6 August 2017.

Catalonia's Government. (2014) White Paper on the National Transition of Catalonia. Generalitat de Catalunya - Government of Catalonia. Department of the Presidency: Barcelona, Spain.

Centre for Cities. (2016) Don't believe the myth: devolution deals are already about much more than the 'big cities' [Online], http://www.centreforcities.org/blog/dontbelieve-myth-devolution-deals-already-much-big-cities, accessed 1 July 2016.

Chouinard S (2014) The EU and federalism. polities and policies compared. Regional \& Federal Studies; 24 (1): 125-126.

Clark G (2016) Cities, Global Cities and Glasgow - Some Reflections. In: Institute, I. P. P., (ed). Glasgow, UK.

Clark G, Couturier J, Moir E and Moonen T (2016) Fiscal Devolution and Scotland's Cities: 'Double Devolution' and Optimising Urban Investment. Glasgow: Fraser of Allander Institute Economic Commentary.

Clark G and Clark G (2014) Nations and the Wealth of Cities: A New Phase in Public Policy. Centre for London: London.

Clark G and Moonen T (2013) The 10 Traits of Globally Fluent Metro Areas. In: Program, M. P. (ed). Brookings, Global Cities Initiative: Washington DC.

Clark G and Moonen T (2016) The role of metropolitan areas in the global agenda of Local and Regional Governments for the 21st Century. The Business of Cities.

Colino C (2008) The Spanish model of devolution and regional governance: evolution, motivations and effects on policy making. Policy \& politics; 36 (4): 573-586. 
Colino CS (2012) Devolution-max á la Basque. A Model for a Scotland within the UK?. The David Hume Institute: Edinburgh.

Connolly CK (2013) Independence in Europe: Secession, Sovereignty, and the European Union. Duke J. Comp. \& Int'l L, 2451: Brussels.

Conversi D (2007) Asymmetry in Quasi-federal and Unitary States. Ethnopolitics; 6 (1): $121-124$

Conversi D (2014) Between the hammer of globalization and the anvil of nationalism: Is Europe's complex diversity under threat? Ethnicities; 14 (1): 25-49.

Convery A and Lundberg TC (2016) Decentralization and the centre right in the UK and Spain: Central power and regional responsibility. Territory, Politics, Governance; 5 (4): 1-18.

Cooke P and Clifton N (2005) Visionary, precautionary and constrained 'varieties of devolution' in the economic governance of the devolved UK territories. Regional Studies; 39 (4): 437-451.

Coppieters B (2010) Secessionist Conflicts in Europe. In: Doyle DH (ed). Secession as an International Phenomenon. University of Georgia Press: Athens, GA / London.

Corijn E (2009) Urbanity as a political project: Towards Post-national European cities. In: Kong L and O'connor J (eds). Creative Economies, Creative Cities: Asian-European Perspectives. Dordrecht: GeoJournal Library.

Costa-Font J and Rico A (2006) Devolution and the interregional inequalities in health and healthcare in Spain. Regional Studies; 40 (8): 875-887.

Cox KR (2010) The problem of metropolitan governance and the politics of scale. Regional Studies; 44 (2): 215-227.

Cox KR (2013) Territory, scale, and why capitalism matters. Territory, Politics, Governance; 1 (1): 46-61.

Crameri K (2015) Political power and civil counterpower: The complex dynamics of the catalan independence movement. Nationalism and Ethnic Politics; 21 (1): 104-120.

Crameri K (2016) Do catalans have 'the right to decide'? Secession, legitimacy and democracy in twenty-first century Europe. Global Discourse; 6 (3): 423-439.

Cuadras-Morató X (2016) Catalonia: A New Independent State in Europe? A Debate Over Secession within the European Union. Routledge: Oxon, UK.

Davidson N (2016) Scotland, Catalonia and the 'right' to self-determination: a comment suggested by Kathryn Crameri's 'Do Catalans Have the "right to decide"?'. Global Discourse; 6 (3): 440-449.

Devine TM (2001) The challenge to Westminster - sovereignty, devolution and independence. Tls-the Times Literary Supplement; 412LQ (5111): 9-9.

Dierwechter Y, Herrschel T and Lintz G (2017) Smart city-regional governance for sustainability? Reflections Series; 20 (4): 1-4.

Economist. (2014) City Devolution. Devo Met: Big English cities are pushing for more power, http://www.economist.com/news/britain/21627697-big-englishcities-are-pushing-more-power-devo-met, [Accessed 1 April 2017.

Economist. (2016) The New Nationalism, http://www.economist.com/news/leaders/ 21710249-his-call-put-america-first-donald-trump-latest-recruit-dangerous, [Accessed 1April 2017.

Eising R (2017) Imperfect public goods and the logic of selective exit in EU interest organisations. West European Politics; 40 (5): 1-21.

Eriksen TH (2010) Ethnicity and Nationalism. Pluto Press: London.

Etherington D and Jones M (2016) The city-region chimera: The political economy of metagovernance failure in Britain. Cambridge Journal of Regions, Economy and Society; 9 (2): 371-389.

European Metropolitan Authorities. (2015) Metropolitan governance in Europe: challenges \& models. In: Tomàs $M(e d)$. Área Metropolitana de Barcelona: Barcelona.

Filibi I, Cornago N and Frosini JO (2011) Democracy With(out) Nations? Old and New Foundations for Political Communities in a Changing World. Servicio Editorial de la Universidad del País Vasco: Vitoria-Gasteiz, Spain.

Financial Times. (2016) Scotland seeks a place betwen the UK and EU: The compromise sought by Nicola Sturgeon could influence others, www.ft.com/ content/5cbe8d1e-9453-11e6-a1dc-bdf38d484582, [Accessed 30 July 2017.

Fishkin JS (2009) When the People Speak: Deliberative Democracy and Public Consultation. Oxford University Press: Oxford.

Flinders M et al (2016) Democracy Matters: Lessons from the 2015 Citizens' Assemblies on English Devolution. In: Project, T. D. M. (ed). ESRC Economic and Social Research Council: Sheffield, UK.

Font Monté À (2016) Colau admet que Schneider ha abandonat el projecte de 'smart cities' i que Cisco hi reduirà el seu pes [Online]. Barcelona: www.ara.cat, http://www.ara.cat/economia/Colau-Schneider-participa-Cisco-smart-cities-cen tre-alier_0_1654034753.html, [Accessed 27 July 2017.

Fricke C (2016) Metropolitan regions as a changing policy concept in a comparative perspective. Raumforschung und Raumordnung. Spatial Research and Planning; 75 (3): 291-305.

Fricke C and Gualini E (2017) Metropolitan regions as contested spaces: The discursive construction of metropolitan space in comparative perspective. Territory, Politics, Governance; 6 (1): 1-23.
Friend JW (2012) Stateless Nations: Western European Regional Nationalisms and the Old Nations. Palgrave Macmillan: London.

Geller A, Rucki K and Fisher J (2015) Gure Esku Dago and the Right to Decide: Viewpoints, Challenges, and Ways Forward. The Advanced Consortium on Cooperation, Conflict, and Complexity \& Scensei LLC: New York.

Geoghegan P (2015) The People's Referendum: Why Scotland Will Never Be the Same Again. Luath Press Limited: Edinburgh, UK.

Gest J (2016) The New Minority: White Working Class Politics in an Age of Immigration and Inequality. Oxford University Press: Oxford.

Gillespie R (2015) Between accommodation and contestation: The political evolution of Basque and Catalan nationalism. Nationalism and Ethnic Politics; 21 (1): 3-23.

Gillespie R (2016) The contrasting fortunes of pro-sovereignty currents in Basque and Catalan nationalist parties: PNV and CDC compared. Territory, Politics, Governance; 5 (4): 1-19.

Giordano B and Roller E (2003) A comparison of city region dynamics in the UK, Spain and Italy: More similarities than differences? Regional Studies; 37 (9): 911-927.

Glaeser EL and Steinberg BM (2017) Transforming cities: Does urbanization promote democratic change? Regional Studies; 51 (1): 58-68.

Gleeson B and Spiller M (2012) Metropolitan governance in the urban age: Trends and questions. Current Opinion in Environmental Sustainability; 4 (4) 393-397.

González S (2004) The role of the Guggenheim Museum in the development of urban entrepreneurial practices in Bilbao. International Journal of Iberian Studies; 16 (3): 177-186.

González S (2011) Bilbao and Barcelona 'in motion'. How urban regeneration 'models' travel and mutate in the global flows of policy tourism. Urban Studies; 48 (7): 1397-1418.

González-Alegre J (2017) Active labour market policies and the efficiency of the European Social Fund in Spanish regions. Regional Studies; 52 (1): 1-14.

Goodwin M, Jones M and Jones R (2005) Devolution, constitutional change and economic development: Explaining and understanding the new institutional geographies of the British state. Regional Studies; 39 (4): 421-436.

Goodwin M, Jones M and Jones R (2012) Rescaling the State: Devolution and the Geographies of Economic Governance. Manchester University Press: Manchester, UK.

Gray C (2015) A fiscal path to sovereignty? The basque economic agreement and nationalist politics. Nationalism and Ethnic Politics; 21 (1): 63-82.

Gray C (2016) Nationalist Politics and Regional Financing Systems in the Basque Country and Catalonia. In: Collection, F. T. D. T., (ed). Bilbao, Spain.

Guibernau M (2013) Secessionism in Catalonia: After democracy. Ethnopolitics; 12 (4): 368-393.

Guibernau M, Rocher F and Adam EC (2014) Introduction: A special section on self-determination and the use of referendums: Catalonia, Quebec and Scotland. International Journal of Politics, Culture, and Society; 27 (1): 1-3.

Harari YN (2017) Nationalism vs. Globalism: The New Political Divide. [Online]. TED, https://www.ted.com/talks/yuval_noah_harari_nationalism_vs_global ism_the_new_political_divide, accessed 1 April 2017.

Harris R and Moffat J (2016) The sources of the Scotland-Rest of the UK productivity gap: Implications for policy. Regional Studies; 51 (9): 1-15.

Harrison J (2007) From competitive regions to competitive city-regions: A new orthodoxy, but some old mistakes. Journal of Economic Geography; 7 (3): 311-332.

Harrison J (2012) Towards the new 'regional world'? ARL; S. 10 bis 21: 9-21.

Harrison J (2017) Constructing alternative paths to city-region policy and governance. In: Deas I and Hincks S (eds). Territorial Policy and Governance: Alternative Paths. Routledge: London.

Harrison J and Hoyler M (2014) Governing the new metropolis. Urban Studies; 51 (11): 2249-2266.

Harrison J, Smith DP and Kinton C (2017) Relational regions 'in the making; Institutionalizing new regional geographies of higher education. Regional Studies; 51 (7): 1-15.

Harvey D (1997) The new urbanism and the communitarian trap. Harvard Design Magazine; 1 (3): 68-69.

Harvey D (2008) The right to the city. New Left Review; 53, 1-16.

Hassan G (2016) Scotland the Bold. Freight Books: Glasgow, UK.

Hazell R (2015) Devolution and the Future of the Union. UCL, T. C. U., (ed). London.

Headlam N and Hepburn P (2015) The old is dying and the new cannot be born, in this interregnum a great variety of morbid symptoms appear. How Can Local Government Survive this Interregnum and Meet the Challenge of Devolution? Representation; 51 (4): 403-415.

Heald D and Mcleod A (2005) Embeddedness of UK devolution finance within the public expenditure system. Regional Studies; 39 (4): 495-518.

Henderson A, Jeffery C, Wincott D and Wyn Jones R (2013) Reflections on the 'Devolution Paradox': A Comparative Examination of Multilevel Citizenship. Regional Studies; 47 (3): 303-322. 
Herrschel T (2002) Governance of Europe's City Regions: Planning, Policy, and Politics. Routledge: London.

Herrschel T and Newman P (2017) Cities as International Actors. Palgrave Macmillan: Basingstoke, UK.

Herszenhorn DM and Von Der Burchard H (2017) President of Catalonia Vows to Go Ahead With Independence Vote, http://www.politico.eu/article/presidentof-catalonia-vows-to-go-ahead-with-independence-vote-referendum-spain, [Accessed 1July 2017.

Hertie School of Governance. (2017) The Governance Report 2017. Oxford University Press: Oxford.

Hirschman AO (1970) Exit, Voice, and Loyalty: Responses to Decline in Firms, Organizations, and States. Harvard University Press: Cambridge, MA.

Holston J and Appadurai A (2008) Cities and citizenship. In: Brenner N, Jessop B, Jones J and Macleod G (eds). State/Space: A Reader. Wiley: Oxford.

House of Lords (2016) English votes for english laws (EVEL). In: Lords HO (ed). Select Committee on the Constitution, 6th Report of Sessions 2016-17. House of Lords: London.

Hutchinson J and Smith AD (1994) Nationalism. Oxford University Press: Oxford; New York.

Ice. (2016) State of the Nation 2016: Devolution. ICE (Institution of Civil Engineers): London.

Iraola I (2015) Nacionalismo Banal y Discurso sobre la Inmigración. El caso Vasco. In: Folguera P, Pereira JC, García C, Izquierdo J, Pallol R, Sánchez R, Sanz C and Toboso P (eds). Pensar con la Historia desde el Siglo XXI. UAM Ediciones: Madrid, Spain

İrepoğlu Carreras Y (2016) Fiscal decentralization and inequality: The case of Spain. Regional Studies, Regional Science; 3 (1): 295-302.

Jamieson D (2016) 2016 in review: The return of the grassroots Scottish independence movement? [Online]. Common Space, https://www.common space.scot/articles/10055/2016-review-return-grassroots-scottish-indepen dence-movement, [Accessed 1 July 2017.

Jensen KK, Fernández C and Brochmann G (2017) Nationhood and Scandinavian naturalization politics: Varieties of the civic turn. Citizenship Studies; 21 (5): $1-19$.

Jeram S and Conversi D (2014) Deliberation and democracy at the end of armed conflict: Post-conflict opportunities in the Basque Country. In: Ugarriza JE and Caluwaerts D (eds). Democratic Deliberation in Deeply Divided Societies: From Conflict to Common Ground. Palgrave MacMillan, London, pp 53-72.

Johns R and Mitchell J (2016) Takeover: Explaining the Extraordinary Rise of the SNP. Biteback Publishing: London.

Jonas AEG and Moisio S (2016) City regionalism as geopolitical processes. Progress in Human Geography; 0 (0): 0309132516679897.

Jones E (2015) Smart city Barcelona. A city of the future? [Online]. Barcelona, http://www.barcelona-metropolitan.com/features/smart-city-Barcelona/, [Accessed 31 July 2017.

Jones M (2016) Polymorphic political geographies. Territory, Politics, Governance; 4 (1): $1-7$.

Jones M, Goodwin M and Jones R (2005) State modernization, devolution and economic governance: An introduction and guide to debate. Regional Studies; 39 (4): $397-403$

Joumard I and Giorno C (2005) Getting the Most Out of Public Sector Decentralisation in Spain. OECD Publishing: Paris, France.

Judis JB (2016) The Populist Explosion: How the Great Recession Transformed American and European Politics. Columbia Global Reports: New York.

Katz B and Bradley J (2013) The Metropolitan Revolution: How Cities and Metros Are Fixing Our Broken Politics and Fragile Economy. Brookings Institution Press: Washington DC.

Kay J (2009) The Economics of Small States. David Hume Institute: Edinburgh, UK. Keating M (2001) Plurinational Democracy. Stateless Nations in a Post-Sovereignty Era. Oxford University Press: Oxford.

Keating M (2005) Policy convergence and divergence in Scotland under devolution. Regional Studies; 39 (4): 453-463.

Keating M (2014a) Class, sector and nation. Support for minority nationalism among peak interest groups in four Western European countries. Territory, Politics, Governance; 2 (3): 322-337.

Keating M (2014b) Introduction: Rescaling interests. Territory, Politics, Governance; 2 (3): 239-248.

Keating M (2014c) Rescaling the european state: The making of territory and the rise of the meso. Oxford Scholarship Online; 52 (1): 38.

Keating M (2017a) Contesting European regions. Regional Studies; 51 (1): 9-18.

Keating M (2017b) What's Next for Catalonia? [Online]. Edinburgh: Centre on Constitutional Change, http://www.centreonconstitutionalchange.ac.uk/blog/ what-next-catalonia-0, [Accessed 31 July 2017.

Keating M and Frantz MD (2004) Culture-led strategies for urban regeneration: a comparative perspective on Bilbao. International Journal of Iberian Studies; 16 (3): 187-194.

Keating M and Harvey M (2014) Small Nation in a Big World: What Scotland Can Learn. Luath Press: Edinburgh.
Keating M and Mcewen N (2005) Introduction: Devolution and public policy in comparative perspective. Regional \& Federal Studies; 15 (4): 413-421.

Khanna P (2014) Dismantling Empires Through Devolution. The Atlantic [Online], https://www.theatlantic.com/international/archive/2014/09/strongerthan-democracy/380774/, accessed 31 July 2017.

Khanna P (2016a) Brexit was not the will of the people, but the will of the provinces. Quartz [Online], https://qz.com/717820/brexography-even-if-theuk-breaks-up-great-britain-is-no-island-nation/, [Accessed 31 July 2017.

Khanna P (2016b) Connectography: Mapping the Global Network Revolution. Weidenfeld \& Nicholson: London.

Klinke A (2016) Dynamic multilevel governance for sustainable transformation as postnational configuration. Innovation: The European Journal of Social Science Research; 30 (3): 1-27.

Kyriacou AP and Morral-Palacín N (2015) Secessionism and the quality of government: Evidence from a sample of OECD countries. Territory, Politics, Governance; 3 (2): 187-204

Larrea AP (1992) En el ecuador del concierto económico vasco de 1980. Comisión de Bizkaia, Real Sociedad Bascongada de los Amigos del País: Bilbao, Spain.

Leyland P (2011) The multifaceted constitutional dynamics of U.K. devolution. International Journal of Constitutional Law; 9 (1): 251-273.

Los B, Mccann P, Springford J and Thissen M (2017) The mismatch between local voting and the local economic consequences of Brexit. Regional Studies; 51 (5): 786-799.

Macwhirter I (2015) Tsunami: Scotland's Democratic Revolution. Freight Books: Glasgow, UK.

Madgwick PJ (1982) Devolution or federalism - options for a United-Kingdom Burrows, B, Denton, G. Welsh History Review; 11 (1): 126-127.

Mann R and Fenton S (2017) The nationalist alternative: Nation and class in Scotland. In: Mann R and Fenton S (eds). Nation, Class and Resentment: The Politics of National Identity in England, Scotland and Wales. London. Palgrave Macmillan: United Kingdom.

Martí D and Cetrà D (2016) The 2015 Catalan election: a de facto referendum on independence? Regional \& Federal Studies; 26 (1): 107-119.

Massetti E (2009) Explaining regionalist party positioning in a Multi-dimensional ideological space: A framework for analysis. Regional \& Federal Studies; 19 (45): 501-531.

Massetti E and Schakel AH (2013) Ideology matters: Why decentralisation has a differentiated effect on regionalist parties' fortunes in Western democracies. European Journal of Political Research; 52 (6): 797-821.

Massetti E and Schakel AH (2016) Between autonomy and secession: Decentralization and regionalist party ideological radicalism. Party Politics; 22 (1): $59-79$.

Massetti E and Schakel AH (2017) Decentralisation reforms and regionalist parties' strength: Accommodation. Empowerment or Both? Political Studies; 65 (2): 432-451.

McAngus C (2015) Do Stateless-Nationalist-Regionalist-Parties differ from other party types? Comparing organisation reform processes in Playd Cymru and the Scottish National Party. Political Studies Association Annual Conference Sheffield.

McGrattan C and Williams S (2017) Devolution and identity: Multidirectionality in 'Welshness' and 'Northern Irishness'. Regional \& Federal Studies; 27 (4): 1-18.

McGregor P and Swales K (2005) Economics of devolution/decentralization in the UK: Some questions and answers. Regional Studies; 39 (4): 477-494.

McLean I (2001) Scotland: Towards Quebec - or Slovakia? Regional Studies; 35 (7): 637-644.

Mediapro. (2017) Las Cloacas de Interior. Diario Público, https://www.youtube. com/watch?v $=$ j6W58CnQQNs, [Accessed 31 July 2017.

Mitchell J (2002) England and the centre. Regional Studies; 36 (7): 757-765.

Moffitt B (2016) The Global Riese of Populism: Performance, Political Style, and Representation. Stanford University Press: Redwood, CA.

Moisio S, Jonas AEG (2017) City-regions and city-regionalism. In: Paasi A, Harrison J and Jones M (eds). Handbook on the Geographies of Regions and Territories. Edward Elgar: Northampton, UK.

Moisio S and Paasi A (2013a) Beyond state-centricity: Geopolitics of changing state spaces. Geopolitics; 18 (2): 255-266.

Moisio S and Paasi A (2013b) From geopolitical to geoeconomic? The changing political rationalities of state space. Geopolitics; 18 (2): 267-283.

Molina I (2017) The EU Variegated Responses to Secessionism: OneSizeDoesNotFit Scotland and Catalonia. In: Oxford, S. a. S. C., (ed).Oxford.

Moore M (1998) National Self-Determination and Secession. Oxford University Press: Oxford.

Moore S (2017) Brexit was an English vote for independence - You can't begrudge the Scots the same, https://www.theguardian.com/commentisfree/2017/mar/15/ brexit-was-an-english-vote-for-independence-you-cant-begrudge-the-scotsthe-same, [Accessed 31 July 2017.

Moreno L (1986) Decentralisation in Britain and Spain: The Cases of Scotland and Catalonia. Edinburgh: University of Edinburgh.

Moreno L (2001) The Federalization of Spain. Frank Cass/Routledge: London. 
Moreno L (2002) Decentralization in Spain. Regional Studies; 36 (4): 399-408.

Moreno L (2015) Catalonia's in(ter)dependence and Europeanization. Instituto de Políticas y Bienes Públicos (IPP) CSIC Working Paper (2015-07).

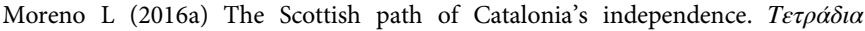

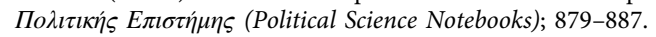

Moreno L (2016b) Theory and practice of paradiplomacy: Subnational governments in international politics. Regional \& Federal Studies; 26 (2): $287-288$.

Morgan K (2001) The new territorial politics: Rivalry and justice in Postdevolution Britain. Regional Studies; 35 (4): 343-348.

Morgan K (2002) English question: Regional perspectives on a fractured nation. Regional Studies; 36 (7): 797-810.

Morgan K (2007) The polycentric state: New spaces of empowerment and engagement? Regional Studies; 41 (9): 1237-1251.

Morgan K (2014) The rise of metropolitics: Urban governance in the age of the city-region. In: Bradford $\mathrm{N}$ and Bramwell A (eds). Governing Urban Economies: Innovation and Inclusion in Canadian City Regions. University of Toronto Press: Toronto.

Morgan KO (1999) Divided we stand (Historical roots of devolution in Scotland and Wales). History Today; 49 (5): 24-26.

Morozov E and Bria F (2017) Roundtable Session - A New Deal on Data: What role for Cities? Smart City Expo World Congress. Smart City Expo Barcelona: Barcelona, Spain.

Mulholland E and Berger G (2017) Multi-level governance and vertical policy integration: Implementation of the 2030 agenda for sustainable development at all levels of government. In: Esdn Quarterly Report 43. (ed). ESDN Office: Vienna, Austria.

Müller J-W (2016) What is Populism?. University of Pennsylvania Press: Philadelphia, PA.

Mumford L (1938) The Culture of Cities. Harcourt Brace: New York.

Mylonas H and Shelef N (2017) Methodological challenges in the study of stateless nationalist territorial claims. Territory, Politics, Governance; 5 (2): 145-157.

New York Times. (2005) Madrid rejects Basque autonomy plan [Online]. NYC: New York Times, http://www.nytimes.com/2005/02/02/world/europe/madridrejects-basque-automony-plan.html, [Accessed 28 July 2017.

O'Brien P, Pike A and Tomaney J (2004) Devolution, the governance of regional development and the trade union congress in the North East region of England. Geoforum; 35 (1): 59-68.

OECD. (2012) Redefining "Urban": A New Way to Measure Metropolitan Areas. OECD Publishing: Paris, France.

OECD. (2015) The Metropolitan Century. OECD Publishing: Paris, France.

OECD. (2016) OECD Regions at a Glance 2016. OECD Publishing: Paris.

OECD/KIPF. (2016) Fiscal Federalism 2016. OECD Publishing: Paris, France.

Ohmae K (1993) The Rise of the Region State. Foreign Affairs; 72 (2): 78-87.

Ohmae K (1995) The End of the Nation-State: the Rise of Regional Economies. Simon and Schuster Inc.: New York.

Ortiz PB (2014) The Art of Shaping the Metropolis. McGraw-Hill Education: New York.

Overman HG (2017) CEP study: The UK areas that will be hit most (and least) by Brexit [Online]. London: EUROPP European Politics and Policy, http://blogs. lse.ac.uk/europpblog/2017/07/27/cep-study-the-uk-areas-that-will-be-hit-mostand-least-by-brexit/, [Accessed 27 July 2017.

Panara C and Varney MR (2017) Multi-level governance in the EU and EU democracy: Democratic legitimacy, democratic accountability and transparency of the European offices of the English local authorities in Brussels. Regional \& Federal Studies; 27 (2): 1-18.

Park B-G (2017) New spatial readings of the state. Territory, Politics, Governance; 5 (1): $1-4$.

Parr JB (2017) The northern powerhouse: A commentary. Regional Studies; 51 (3): $490-500$

Pattie C and Johnston R (2017) Sticking to the union? Nationalism, inequality and political disaffection and the geography of Scotland's 2014 independence referendum. Regional \& Federal Studies; 27 (1): 83-96.

Paun A, Rutter J and Nicholl A (2016) Devolution as a Policy Laboratory. Alliance for Useful Evidence. Institute for Government and Carnegie UK Trust: London.

Penny L (2016) I want my country back, http://www.newstatesman.com/politics/ uk/2016/06/i-want-my-country-back, [Accessed 27 July 2017.

Pike A (2002) Post-devolution blues? Economic development in the Anglo-Scottish borders. Regional Studies; 36 (9): 1067-1082.

Pike A (2014) Post-Referendum Blues? Regions Magazine; 296 (1): 5-6.

Pike A, Kempton L, Marlow D, O’Brien P and Tomaney J (2016) Decentralisation: Issues, Principles and Practice. Centre for Urban and Regional Development Studies, Newcastle University: Newcastle, UK.

Plangger M (2017) Building something beautiful with stones: How regions adapt to, shape and transform the EU opportunity structure. Regional \& Federal Studies; 28 (1): 1-24.
Polverari L (2015) Does devolution increase accountability? Empirical evidence from the implementation of European Union cohesion policy. Regional Studies; 49 (6): 1074-1086.

Purcell M (2013) The right to the city: The struggle for democracy in the urban public realm. Policy and Politics; 41 (3): 311-327.

Purcell M (2014) Possible worlds: Henri Lefebvre and the right to the city. Journal of Urban Affairs; 36 (1): 141-154.

Qvortrup M (2014) Referendums on independence, 1860-2011. The Political Quarterly; 85 (1): 57-64.

Qvortrup M (2015) Power to the people! But How? The different uses of referendums around the world. Political Studies Review; 13 (1): 37-45.

Randall J and Casebourne J (2016) Making Devolution Deals Work. Institute for Government: London.

Redding N (2015) AC4 Partners with Scensei for Rerport on the Basque Civil Society Group Gure Esku Dago [Online]. Bilbao: Columbia University, Advanced Consortium on Cooperation, Conflict, and Complexity, http://ac4 ei.columbia.edu/2015/06/25/ac4-partners-with-scensei-for-report-on-the-bas que-civil-society-group-gure-esku-dago/, [Accessed 27 July 2017.

Regelmann A-C (2016) Minority nations in the age of uncertainty: New paths to national emancipation and empowerment. Regional \& Federal Studies; 26 (2): 289-290.

Requejo F (2015) National pluralism, recognition, federalism and secession (or Hegel was a clever guy). In: Gagnon AG, Keil S and Mueller S (eds). Understanding Federalism and Federation. Ashgate: London.

Rezvani DA (2016) Partial independence beats full independence. Territory, Politics, Governance; 4 (3): 269-296.

Ríos Fernández M (2017) Catalunya en Comú y la cuestión nacional [Online]. Barcelona: Agenda Pública, http://agendapublica.elperiodico.com/catalunyacomu-la-cuestion-nacional/, [Accessed 27 July 2017.

Rodríguez-Pose A and Gill N (2005) On the 'economic dividend' of devolution. Regional Studies; 39 (4): 405-420.

Rokkan S, Flora P, Kuhnle S and Urwin DW (2007) State Formation, Nationbuilding, and Mass Politics in Europe: The Theory of Stein Rokkan. Oxford University Press: Oxford.

Romaniello M (2014) Federalism beyond federations. Asymmetry and processes of resymmetrisation in Europe. Regional \& Federal Studies; 24 (1): 126-128.

Rovira I, Martínez M (2016) Les Mobilitzaciones pel dret a decidir: una fenomenologia de l'abast social i simbòlic de la reivindicació. In: Homs O (ed). Societat Catalana 2014-2015. Associació Catalana de Sociologia. Filial de I'Institut d'Estudis Catalans: Barcelona, Spain.

Royles E (2017) Sub-state diplomacy: Understanding the international opportunity structures. Regional \& Federal Studies; 27 (4): 1-24.

Ruacan IZ (2017) Beyond the Westphalian rainbow: a dissident theory of supranational systems. Territory, Politics, Governance; 6 (1): 1-18.

Ruiz C and Fernández PM (2003) ¿Aprobaron los vascos la Constitución? Revista de Estudios Políticos (Nueva Época); 122, 167-168.

Ruiz-Vieytez EJ (2016a) Basque national movements and new diversity challenges in a post-violence scenario. In: Kolas $\AA$ and Ibarra P (eds). Basque Nationhood. Towards a Democratic Scenario. Peter Lang: Oxford.

Ruiz-Vieytez EJ (2016b) Minority nations and self-determination: a proposal for the regulation of sovereignty processes. International Journal on Minority and Group Rights; 23 (2016): 402-421.

Sage D (2014) The scottish national party: Transition to power. Regional \& Federal Studies; 24 (4): 532-533.

Sandford M (2002) What place for england in an asymmetrically devolved UK? Regional Studies; 36 (7): 789-796.

Sandford M (2017) Signing up to devolution: The prevalence of contract over governance in English devolution policy. Regional \& Federal Studies; 27 (1) $63-82$.

Sanjaume-Calvet M, Gagnon AG (2014) Cataluña: federalismo y derecho a decidir. In: Pastor J (ed). Anuario del conflicto social. Universitat de Barcelona: Barcelona, Spain.

Sassen S (2001) The Global City: New York, London, Tokyo. Princeton University Press: Princeton, NJ.

Sassen S (2002) Towards post-national and denationalized citizenship. In: Isin EF and Turner BS (eds). Handbook of Citizenship Studies. SAGE Publications Ltd.: London.

Sassen S (2013) When territory deborders territoriality. Territory, Politics, Governance; 1 (1): 21-45.

Sato J (2014) Resource politics and state-society relations: Why are certain states more inclusive than others? Comparative Studies in Society and History; 56 (3): $745-773$.

Scott A (2002) Global City-Regions: Trends, Theory, Policy. Oxford University Press: Oxford.

Scott C and Copeland E (2016) Smart Devolution: Why Smarter Use of Technology and Data are Vital to the Success of City Devolution. Policy Exchange: London.

Scottish Cities Alliance. (2017) City Key Facts 2016. Scottish Cities Alliance: Edinburgh, UK 
Scottish Government. (2013) White Paper: Scotland's Future: Your Guide to An Independent Scotland. Scottish Government: Edinburgh.

Scottish Government. (2016) Fairer Scotland: Action Plan. Scottish Government: Edinburgh.

Sellers JM (2002) The nation-state and urban governance: Toward multilevel analysis. Urban Affairs Review; 37 (5): 611-641.

Sellers JM and Walks RA (2013) Introduction: The metropolitanisation of politics. In: Sellers JM, Kübler D, Walter-Rogg M and Walks RA (eds). The Political Ecology of the Metropolis. ECPR Press: Colchester, UK.

Serrano I (2013) Just a matter of identity? Support for independence in Catalonia. Regional \& Federal Studies; 23 (5): 523-545.

Serrano-Gaztelurrutia S (2012) El concierto económico vasco ante el juez comunitario: la judicialización de las Normas Forales tributarias en el ámbito juridico europeo: situación vigente (ayudas de Estado) y perspectivas de futuro. Organismo Autónomo del Gobierno Vasco: Oñati, Spain.

Shaw K and Tewdwr-Jones M (2017) 'Disorganised devolution': Reshaping metropolitan governance in England in a period of austerity. Raumforsch und Raumordn; 75211-75224.

Shea Baird K (2017) A new international municipalist movement is on the risefrom small victories to global alternatives [Online]. London: Open Democracy, https://www.opendemocracy.net/can-europe-make-it/kate-shea-baird/newinternational-municipalist-movement-is-on-rise-from-small-vic, [Accessed 27 July 2017.

Simonsen K (2004) 'Europe', national identities and multiple others. European Urban and Regional Studies; 11 (4): 357-362.

Sorens J (2017) Federalism isn't unfair [Online], https://pileusblog.wordpress.com/ 2017/07/25/federalism-isnt-unfair/amp/, [Accessed 27 July 2017.

Spanish Government. (2017) Acuerdo para el Apoyo de los Presupuesto Generales del Estado para 2017 (PP-PNV). Spanish Government: Madrid, Spain.

Stanic A (2016) Preparing for Independence: Lessons learned from newly born states. Centre Maurits Coppieters: Brussels.

Steele W (2017) Henri Lefebvre: Spatial politics, everyday life and the right to the city. Urban Policy and Research; 35 (2): 1-2.

Stiglitz JE (2015) Devolution, independence, and the optimal provision of public goods. Economics of Transportation; 4 (1-2): 82-94.

Strategy GK (2017) Devolution Disconnected: Political Priority, Public Apathy. GK strategy and Onefourzero Group: London.

STV. (2017) Thousands in pro-independence march through Glasgow [Online], https://stv.tv/news/west-central/1390331-thousands-in-pro-independencemarch-through-glasgow, [Accessed 27 July 2017.

Suszycki AM et al (2010) Multiplicity of Nationalism in Contemporary Europe. Rowman \& Littlefield/Lexington Books: London.

Sutherland C (2012) Nationalism in the Twenty-First Century: Challenges and Responses. Palgrave Macmillan: London.

Therborn G (2017) Cities of Power. Verso: London and New York.

Tomàs M (2016) Explaining Metropolitan Governance. The Case of Spain. Raumforschung und Raumordnung; 1-10.

Travers T (2017) The Power to the Regions: Why More Devolution Makes Sense, https://www.theguardian.com/public-leaders-network/2017/feb/08/powerregions-more-devolution-cities-brexit, [Accessed 27 July 2017.

Turp D and Sanjaume-Calvet M (2016) The Emergence of A Democratic Right to Self-Determination in Europe. Centre Maurits Coppieters: Brussels, Belgium.

Uriarte PL (2015) El Concierto Económico Vasco: Una visión personal. Concierto Plus: Bilbao, Spain.

Vallbé J-J, Magre J and Tomàs M (2015) Being metropolitan: The effects of individual and contextual factors on shaping metropolitan identity. Journal of Urban Affairs: 1-18.

Walker D (2010) 'Metropolitanisation' in economic development: Exclusion and marginalization through the dominance of national policies. An English perspective. Regions Magazine; 279 (1): 14-15.

Walt V (2015) Barcelona: The most wired city in the world [Online]. Barcelona: Fortune, http://amp.timeinc.net/fortune/2015/07/29/barcelona-wired-city, [Accessed 27 July 2017.

West E (2015) The Diversity Illusion: What We Got Wrong About Immigration and How to Solve It. Gibson Square Books: London.

Wilkins RB (2004) Federalism: Distance and devolution. Australian Journal of Politics and History; 50 (1): 95-101.
Willett J (2015) Devolution and localism in England. Regional \& Federal Studies; 25 (3): 325-327.

Winlow S, Hall S and Treadwell J (2017) The Rise of the Right: English Nationalism and the Transformation of Working-Class Politics. Policy Press: Bristol, UK.

Woertz E (2017) Populism in Europe: From Symptom to Alternative?. CIDOB (Barcelona Centre for International Affairs): Barcelona, Spain.

Wojan TR (2017) Metaphors of regional policy: Cities as engines, multilevel governance in gardens. Regional Studies; 51 (2): 324-335.

Zabalo J et al (2016) Imagining the Basque State: Opinions and Attitudes With Respect to a Basque State in Euskal Herria. A Quantitative and Qualitative Study. Parte Hartuz Ikerketa taldea, Ipar Hegoa Fundazioa: Bilbao, Spain.

Zabalo J, Mateos T and Iraola I (2013) Conflicting nationalist traditions and immigration: The Basque case from 1950 to 1980. Nations and Nationalism; 19 (3): 513-531.

Zabalo J and Saratxo M (2015) ETA ceasefire: Armed struggle vs. political practice in Basque nationalism. Ethnicities; 15 (3): 362-384.

Zabalo J, Soto I and Mateos T (2012) The right to self-determination and Basque Nationalism: A polyvalent debate. Ethnopolitics; 11 (3): 318-340.

Zamorano M (2017) Presentación del monográfico. Introducción: Postpolítica y vigencia del nacionalismo en el Estado español. Debats. Revista de cultura, poder $y$ sociedad; 131 (1): 12.

\section{Data availability}

Data sharing is not applicable to this article as no datasets were generated or analysed during the current study.

\section{Acknowledgements}

The fieldwork research was supported by Bizkaia Talent and Bilbao Metrópoli-30 funded by the EU-Marie Curie Actions-MSCA-SmartCityRegions-COFUND-2015-Regional Programmes under Grant AYD-000-268. The research project was supported by the European Commission (EC) under Grant H2020-SCC-691735-REPLICATE 2016-2021 (www.replicate-project.eu); the Economic and Social Research Council (ESRC) under Grant Urban Transformations 2016-2018 (www.urbantransformations.ox.ac.uk); the Regional Studies Association (RSA) under Grant "Smart City-Regional Governance for Sustainability" Research Network 2016-2018 and the Early Career Grant holder 20142015; the Brussels Centre for Urban Studies (BCUS) under the Visiting Research Fellowship Scheme 2016 (http://urbanstudies.brussels/people/igor-calzada); 'Political Innovation: Constitutional Change, Self-Government, the Right to Decide, and Independence' 2015 Summer School of the University of the Basque Country (UPVEHU) (www.berrikuntzapolitikoa.eus); and Ikerbasque, the Basque Foundation for Science 2012-2014 [Grant RDKR-2012-17] (www.cityregions.org).

\section{Additional information}

Competing interests: The author declares that there are no competing financial interests.

Reprints and permission information is available at http://www.palgrave-journals.com/ pal/authors/rights_and_permissions.html

How to cite this article: Calzada I (2017) Metropolitan and city-regional politics in the urban age: why does "(smart) devolution" matter?. Palgrave Communications. 3:17094 doi: $10.1057 /$ palcomms.2017.94.

Publisher's note: Springer Nature remains neutral with regard to jurisdictional claims in published maps and institutional affiliations.

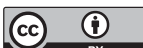

This work is licensed under a Creative Commons Attribution 4.0 International License. The images or other third party material in this article are included in the article's Creative Commons license, unless indicated otherwise in the credit line; if the material is not included under the Creative Commons license, users will need to obtain permission from the license holder to reproduce the material. To view a copy of this license, visit http://creativecommons.org/licenses/by/4.0/

(C) The Author(s) 2017 